\title{
Extracellular Vesicles from Adipose Tissue Stem Cells in Diabetes and Associated Cardiovascular Disease; Pathobiological Impact and Therapeutic Potential
}

\author{
Alina Constantin ${ }^{+}\left(\mathbb{D}\right.$, , Alexandru Filippi ${ }^{\dagger}$, Nicoleta Alexandru, Miruna Nemecz and \\ Adriana Georgescu * \\ Institute of Cellular Biology and Pathology "Nicolae Simionescu" of Romanian Academy, \\ 050568 Bucharest, Romania; alina.constantin@icbp.ro (A.C.); alexandru.filippi@icbp.ro (A.F.); \\ nicoleta.alexandru@icbp.ro (N.A.); miruna.nemecz@icbp.ro (M.N.) \\ * Correspondence: adriana.georgescu@icbp.ro; Tel.: +40-21-3194-518 \\ + These authors had equal contribution to the manuscript.
}

Received: 11 November 2020; Accepted: 14 December 2020; Published: 16 December 2020

\begin{abstract}
Adipose tissue-derived stem cells (ADSCs) are pluripotent mesenchymal stem cells found in relatively high percentages in the adipose tissue and able to self-renew and differentiate into many different types of cells. "Extracellular vesicles (EVs), small membrane vesicular structures released during cell activation, senescence, or apoptosis, act as mediators for long distance communication between cells, transferring their specific bioactive molecules into host target cells". There is a general consensus on how to define and isolate ADSCs, however, multiple separation and characterization protocols are being used in the present which complicate the results' integration in a single theory on ADSCs' and their derived factors' way of action. Metabolic syndrome and type 2 diabetes mellitus (T2DM) are mainly caused by abnormal adipose tissue size, distribution and metabolism and so ADSCs and their secretory factors such as EVs are currently investigated as therapeutics in these diseases. Moreover, due to their relatively easy isolation and propagation in culture and their differentiation ability, ADSCs are being employed in preclinical studies of implantable devices or prosthetics. This review aims to provide a comprehensive summary of the current knowledge on EVs secreted from ADSCs both as diagnostic biomarkers and therapeutics in diabetes and associated cardiovascular disease, the molecular mechanisms involved, as well as on the use of ADSC differentiation potential in cardiovascular tissue repair and prostheses.
\end{abstract}

Keywords: adipose tissue-derived stem cells; extracellular vesicles; diabetes; cardiovascular disease

\section{Introduction}

The adipose tissue has been considered for many years an inert storage depot for nutrients, but now many evidences show that adipose tissue has various physiological roles that include regulation of metabolism, immunity and endocrine function. The anatomical location in coordination with the dynamic changes of cellular component has a prominent effect on the biology of adipose tissue. Given its central role in regulation of energy homeostasis and because obesity-related disorders such as diabetes, metabolic syndrome and cardiovascular diseases have reached an epidemic magnitude, extensive interest has been payed to establish a broad map of adipose tissue cellular composition and the intercellular communication that mediate pathologic responses.

The adipose tissue is generally divided into two distinct types, white adipose tissue (WAT) and brown adipose tissue (BAT), the first acting to store and mobilize triglycerides, and the second having the leading function of burning fatty acids and glucose for heat production, a process known as adaptive (non-shivering) thermogenesis [1]. 
WAT is found throughout the body but is mainly organized into anatomically distinct depots: subcutaneous WAT, which is found under the skin, and visceral WAT, which is located within the body cavities, surrounding the major organs. In addition to subcutaneous and visceral fat, WAT can be found in many other areas: breasts, on the neck and upper back, extremities, in the retro-orbital space, and within bone marrow. During the last years, a third form of adipose tissue has been characterized in rodents and humans. BAT is found as depots in newborns (in perivascular and peri-organ visceral areas) but also in adults (in cervical, supraclavicular, mediastinal, and suprarenal regions) [2]. Both visceral and subcutaneous WAT depots have been shown to harbor thermogenic adipocytes, and originally in subcutaneous WAT they were called beige, whilst in visceral WAT they were termed brite [3]. The process of browning and the recruitment of beige adipocytes typically occurs in response to certain stimuli, particularly exposure to cold or to $\beta 3$-adrenergic stimulation $[1,3,4]$. Beige adipocytes are located within WAT depots, and are morphologically and functionally comparable to brown adipocytes $[3,5]$. Beige adipocytes express uncoupling protein 1 (UCP-1), a master regulator of thermogenesis in BAT $[3,6]$.

WAT is composed of a mixed population of cells including lipid-filled mature adipocytes, and a stromal vascular fraction (SVF) that contains stromal cells (adipose stem cells, blood lineage cells, vascular cells, fibroblasts) and immune cells, the percentage of each being in a dynamic state. Healthy WAT is characterized by the presence of numerous and smaller adipocytes resulted from differentiated progenitor cells. However, it is known that WAT is highly plastic and responds to different stimuli by continuous remodeling, i.e., during periods of excess energy intake it expands by both hypertrophy (increase in cell size) and/or hyperplasia (increase in cell number) [7-9]. The xplanation for these processes comes from the fact that within WAT there are subpopulations of adipocyte progenitor cells which exhibit different secretory pro-inflammatory or fibrotic phenotypes influencing their differentiation state. Thus, identifying different subpopulations of progenitor cells and their interaction with non-stromal resident cells in WAT it is a crucial issue in order to understand how fat homeostasis is regulated.

It has been showed that expansion of visceral WAT is mainly due to adipocyte hypertrophy that is linked to inflammation and insulin resistance [10,11]. In murine models, high fat feeding leads to adipocyte hypertrophy in both visceral and subcutaneous WAT, whereas adipogenesis is thought to occur primarily in visceral WAT [7,8]. The ability of adipose tissue to expand by hyperplasia confers a protective advantage against insulin sensitivity and metabolic disease risk by the recruitment of adipocyte progenitor cells and commitment to the adipose lineage [10,12]. Chronic overnutrition forces adipocytes to enlarge, to store more triglycerides and when their buffering capacity is exceeded, hypertrophied adipocyte death coupled with the accumulation of pro-inflammatory macrophages and fibrotic cells into the adipose tissue leads to ectopic fat accumulation in muscle and liver and to systemic insulin resistance [13,14].

Differences between visceral and subcutaneous adipose tissue exist also in terms of the number of isolated adipose tissue-derived stem cells (ADSCs) and their ability to expand in vitro. SFV cell number isolated from omental adipose tissue was significantly higher than that from subcutaneous adipose tissue in human donors [15]. In addition, it was noted that the yield of ADSCs isolated from each gram of visceral fat was significantly greater than that from subcutaneous fat, implying that the visceral adipose tissue contained more ADSCs [16].

Extracellular vesicles (EVs) are different types of submicron vesicles derived from nearly all cells in response to cell activation, stress or apoptosis. Based on the size, morphology, and mechanism of biogenesis, they are divided in exosomes and ectosomes. Exosomes (50-100 nm) are small vesicles exocyted from multivesicular bodies (MVBs) after receptor-mediated endocytosis. Ectosomes (microvesicles (MVs) or microparticls (MPs)) are slightly larger vesicles (100-500 nm) compared with exosomes and are also cell specific as they are released from plasma membrane by budding [17].

Metabolic syndrome is a multifactorial disease and involves numerous cell types, tissues, organs and humoral factors (cytokines, growth factors and miRNA molecules, many of them being 
encapsulated in circulating EVs). Almost any type of cells (endothelial cells, lymphocytes, T cells, macrophages, renal cells, cancer cells and stem cells) can release EVs in physiological state, and number of these submicron vesicular membrane structures is increased during pathological processes. EVs can exhibit characteristics (RNAs, DNA and lipids) of their parent cell of origin and may provide diagnostic and prognostic value in metabolic dysfunction and cardiovascular diseases [18-20]. EVs can be isolated from plasma, urine, cerebral spinal fluid, lymph and conditioned media from cell culture by different methods.

Mesenchymal stem cells (MSCs) are multipotent cells with high proliferative, self-renewal, multi-lineage differentiation, and regenerative potential. MSCs reside in variable amount in adult organs of human bodies with high regeneration and differentiation capacity, but bone marrow, human umbilical cord and adipose tissue are important origins of MSCs for researches. MSCs from these sources exhibit common features in terms of proliferation and differentiation capacity, but their regenerative potential is site-specific. Previous studies [21,22] showed that MSCs convey their reparative effects by releasing EVs, including small and large EVs. Recently, MSC-derived EVs as a cell-free therapeutic alternative have gained considerable interest. More than that, EVs can also be used as a vehicle to deliver bioactive factors. EVs derived from bone marrow mesenchymal stem cells (BM-MSCs) have been used to treat cartilage defects or osteoarthritis which are related to bone diseases [23,24], renal injury [25] or Graft Versus-Host Disease [26]. Small EVs derived from BM-MSCs are widely used in the treatment of myocardial infarction (MI). An important mechanism behind the regenerative potential of EV-MSCs is the immune-regulatory properties of these vesicles. In a recent paper, small EVs secreted by BM-MSCs were incorporated into alginate hydrogel to increase their retention in the heart, have been showed to reduce the apoptosis of cardiomyocytes and promoted the polarization of macrophages [27].

Among MSC-dervied EVs, ADSC-derived EVs stand out as novel mediators and biomarkers in the crosstalk between adipose tissue and other organs/tissues relevant in obesity and metabolic diseases. In recent years, EVs from ADSCs have attracted much attention for their role in metabolic dysfunction, in particular, obesity and its complications, but their role in diabetes and associated cardiovascular disease was very little discussed.

Diabetic nephropathy represents one of the most relevant chronic complications of diabetes and the major cause of end-stage renal failure [28]. At present, available clinical biomarkers including glomerular filtration rate (GFR), proteinuria and urinary sediment evaluation do not allow a specific diagnosis neither clarify disease staging. Therefore, the finding of non-invasive biomarkers could hinder the use of kidney biopsy, a procedure implying complication risks. Urine is an ideal source of biomarkers, particularly for diseases of the kidney and urinary tract, because it can be conveniently collected in large amounts without risk to the patient. Recent studies revealed that expression of urinary exosomal miRNA is changed in patients with type 2 diabetes mellitus (T2DM) [29,30]. Urinary exosomal miRNA content is altered in patients suffering from type 1 diabetes mellitus (T1DM) with incipient diabetic nephropathy and micro-albuminuria resulting in an up-regulation of miR-130a and miR-145 and a down-regulation of miR-155 and miR-424 [31].

Investigation of the pathophysiology of EVs and relevant mechanisms provides new opportunities in diagnosing and combatting metabolic disorders by the development of new therapeutic strategies in metabolic diseases such as diabetes and associated cardiovascular disease.

\section{Adipose Tissue-Derived Stem Cells}

\subsection{Identification and Molecular Characteristics of Adipose Tissue Stem Cells}

Isolation of cells from rodent adipose tissue was pioneered by Rodbell and collaborators in the 1960s. Later, in the 2001s, Zuk and collaborators described the isolation and cultivation of stem cells harvested from human lipoaspirate [32], and afterwards Bunnell and collaborators described the isolation of ADSCs from human adipose tissue. ADSCs are mesenchymal stem cells (MSCs) that are 
resident in large amounts in the adipose tissue and share key characteristics with bone marrow-MSCs, including the ability to adhere to plastic, to form fibroblastic like colonies (called CFU-F), and also their high proliferative capacity and remarkable capability to differentiate in vitro into mesenchymal lineages: osteoblasts, chondrocytes, adipocytes and skeletal myocytes [33,34]. It has been found that the SVF from adipose tissue provides 500 times more stem cells than bone marrow (only $0.01-0.001 \%$ ), making ADSCs a reliable source of MSCs [35]. The number of isolated ADSCs can vary, depending on the isolation method. There are many processes for tissue digestion and cell isolation from adipose tissue, as those using collagenase, trypsin, dispase, or related enzymes.

Initially, a very specific panel of positive markers CD105, CD73 and CD90, and lack of CD45, CD34, CD14 or CD11b, CD79 $\alpha$ or CD19, and HLA-DR surface molecules expression was stated to represent the prototypical ADSC hallmark [36]. Additionally, many other molecules have been reported in association with ADSCs, but their expression still remains controversial and is believed to be affected by donor-to-donor variability, differing protocols of isolation and expansion, and diverse experimental techniques. Until now there has been no definitive description of the immunophenotypic characteristics of ADSCs, and other markers were added to the previously reported ones. Of those, CD34, is a hematopoietic marker that has been reported both to be positive in SVF and lose its expression with time and culture passages of ADSCs [37], or to maintain its expression even at late culture passages [38]. Traktuev showed that a population of adipose-derived adherent CD34+ cells are resident pericytes that play an important role in vascular stabilization by reciprocal interaction with endothelial cells [39].

In the last few years, efforts have been made to identify and enrich adipose tissue progenitor cells, and Rodeheffer and collaborators distinguished two sub-populations in the adult murine SVF [40,41]. The two subpopulations of cells were separated by the non-immune cells based on both the lack of expression of CD45, CD31 and Ter119 markers (blood and endothelial cell markers) and the presence of CD29, CD34 and Sca-1/Ly6-A markers (mesenchymal and stem cell markers). The CD45- ${ }^{-}$CD31Ter119- ${ }^{-}, \mathrm{CD}_{2} 9^{+}, \mathrm{CD} 34^{+}, \mathrm{Sca}-1^{+} ; \mathrm{CD} 24^{+}$cells (adipocyte progenitor cells (APCs)) were capable of developing into functional WAT depots when they were transplanted into lipodystrophic mice, while the $\mathrm{CD} 45^{-}, \mathrm{CD} 31^{-}, \mathrm{Ter} 119^{-}, \mathrm{CD} 29^{+}, \mathrm{CD} 34^{+}, \mathrm{Sca}-1^{+}, \mathrm{CD} 24^{-}$cells (preadipocytes), even being adipogenic in vitro, were not able to form WAT depots in vivo [41]. Thus, the CD $24^{+}$subfraction of $\mathrm{CD} 34^{+} \mathrm{Sca}-1^{+}$ cells represent a stem cell-like population, whereas the $\mathrm{CD} 24^{-}$subfraction represents a pool of more committed APCs. Moreover, both populations of cells express platelet-derived growth factor receptor alpha (PDGFR $\alpha$ ), a known marker of the adipocyte precursor cell lineage, and were highly adipogenic in vitro (Berry and Rodeheffer, 2013). Identification of new mice APC markers relevant for the in vivo behavior of APCs in WAT was accomplished by immunofluorescence localization, enlightening that at least a proportion of progenitor cells are located within the perivascular niche of capillaries and microvessels as pericytes $\left(\right.$ PDGFR $\alpha^{+} /$PDGFR $^{+}{ }^{+}$) [42,43]. Furthermore, it was observed that PDGFR $\alpha^{+}$ lineage contributes to all adipocytes in subcutaneous WAT [40] and expression of PDGFR $\alpha$ precedes PDGFR $\beta$ expression in almost all subcutaneous but only in a fraction of visceral ADSCs [44]. PDGFR $\beta^{+}$ expressing cells don't usually differentiate but, when exposed to high fat diet, they turn into adipocytes in visceral WAT, and when exposed to cold, they form beige adipocytes in the subcutaneous depot.

In addition to the adipose precursors CD29, CD34, Sca-1 mentioned above, Wt1 (the protein encoded by the Wilms' tumor 1 gene), known to function as a transcription factor and having post-transcriptional processing roles, is also important for adipocyte differentiation. Wt1 is highly expressed in mesothelial cells able to differentiate into adipocytes when exposed to adipogenic conditions in culture $[45,46]$ and deletion of Wt1 in adult mice results in a considerable loss of fat tissue [47].

Recently, Prx1-Cre has been found to label subcutaneous and periaortic BAT and not visceral adipose tissue. Moreover, a portion of the Prx1-Cre labeled pericardial APCs express Wt1 [36,48]. Additionally, Myf5-Cre and Pax3-Cre are capable of tracing both white and brown depots [49,50], while PDGFR $\alpha$-Cre labels both adipocyte progenitor cells and pre-adipocytes in subcutaneous and visceral depots. Therefore, these lineage tracing studies give valuable information on developmental 
origin of APCs from different adipose tissue depots. Going further, efforts have been made in order to identify subpopulations of adipose stromal cells in each of the fat depots, and the single cell RNA sequencing (scRNAseq) technology, recently developed as a powerful tool to deconvolve tissue heterogeneity came to help [51]. The results obtained with this technology are presented as an atlas of spatial clustering of subpopulation of cells based on log2 expression levels for select genes commonly used to purify adipose stem cells by fluorescent activated cell sorting (FACS) or lineage tracing experiments. Rondini and Granneman showed that more than $70 \%$ of non-immune stromal cells are represented by ADSCs that express genes for previously identified surface markers including PDGFR $\alpha$, CD29 (Itgb1), CD34 (Cd34), and Sca-1 (Ly6a) [52]. There is a general consensus about the presence of two main populations of ADSCs (stated as ADSC1a and ADSC2), with an additional subpopulation (ADSC1b) present in inguinal WAT [53-56]. The relative ratio of total ADSC1 to ADSC2 in adult animals was found to be larger in epididymal WAT than in inguinal WAT. Functional assays suggest that the ADSC1 population expressed genes involved in lipid uptake and was more primed for adipogenesis, and ADSC2 expressed some genes that are associated with inflammation (prostaglandin synthesis), angiogenesis (endothelial cell migration), proteolysis (Pi16, Dpp4), as well as with immune signaling (Cd55) [54-56].

Conventionally, in humans, according to the International Society for Cellular Therapy (ISCT) criteria, mesenchymal stem cells are CD105, CD73 and CD90 positive cells, negative for HLA-DR, CD14, CD34, CD19 and CD45 [57], but other markers have been added later. A recent paper revealed that the following markers are attributed to ADSC phenotype: CD90, CD44, CD29, CD105, CD13, CD73, CD166, CD10, CD49e, and CD59 are positive markers, while CD31, CD45, CD14, CD11b, CD34, CD19, CD56, and CD146 are negative markers [58]. This panel of positive and negative markers on human ADSCs has been developed for in vitro propagated cells but it was observed that freshly isolated SVF contain numerous subpopulations, and to further isolate specific cell types, different combinations of markers have been chosen for FACS separation of cells.

\subsection{Differentiation Potential of Adipose Tissue Stem Cells}

The molecular mechanisms controlling the adipose tissue homeostasis have been intensively studied due to their potential application in the prevention and treatment of obesity and related disorders such as diabetes, dyslipidemia, and cardiovascular diseases. The expansion of adipose tissue as a response to metabolic challenges, either by hyperplasia or by hypertrophy, is strongly dependent on the adipogenic and immunomodulatory potentials of adipose-derived stem cells. Different studies have reported that ADSCs from obese subjects have decreased ability to differentiate into adipocytes in vitro, when compared with those from lean subjects [59-61]. A possible explanation is that the inflammatory cytokines in the adipose tissue from obese subjects impaired adipocyte differentiation [62]. Moreover, numerous studies showed that subcutaneous ADSCs have a higher adipogenic potential than those from visceral depots, both in humans $[63,64]$ and in mice $[65,66]$. The ADSC differentiation capacity is also disrupted in patients with T2DM as indicated by global gene expression profiling revealed that ADSCs from T2DM donors have low levels of adipogenic genes compared with those from non-diabetic donors.

When exposed to specific growth conditions in vitro, ADSCs can be differentiated toward adipogenic [34], osteogenic [67], chondrogenic [68], myogenic [69], and neurogenic lineage [70].

Many transcription factors were shown to impact adipogenesis, some of them having a positive

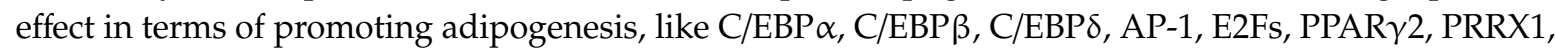
STAT5A, and others inhibiting adipogenesis, GATAs, PREF-1, Wnt-10b, and Wnt-5a, being involved in progenitor cell proliferation. Moreover, some cell cycle proteins such as cyclin D, p21, p27 KIP (cyclin-dependent kinase inhibitors), and estrogen, insulin, IGF-1 (hormones) are involved in adipocyte development [71-73]. C/EBP- $\beta$ and C/EBP- $\delta$ are the first transcription factors induced during adipogenesis and play a crucial role in directing the differentiation process. While C/EBP- $\beta$ synthesis decays, C/EBP- $\alpha$ and PPAR $\gamma 2$ transcription is continuously stimulated by C/EBP- $\alpha$ binding to CEBPs 
regulatory elements. The PPAR $\gamma 2$ transcription is controlled also by transcription factor SREBP1 and KLF family [74,75]. It has been found that PPAR $\gamma$ can promote adipogenesis in C/EBP- $\alpha$-deficient cells [76], but C/EBP- $\alpha$ does not function similarly in the absence of PPAR $\gamma 2$ [77]. In the last phase of adipogenic differentiation, genes associated with mature adipocytes such as fatty acid synthase, glycerophosphate dehydrogenase, acetyl CoA carboxylase, glucose transporter type 4 , insulin receptor, adipocyte-selective fatty acid binding protein (aP2) are markedly expressed, and numerous lipid droplets are formed [78].

Different studies demonstrated that factors and pathways that stimulate osteogenesis inhibit adipogenesis. Conversely, adipogenic induction inhibits osteogenesis [79]. The balance between adipogenesis and osteogenesis is important to keep homeostasis in the organism. Osteogenic differentiation of ADSCs in vitro can be influenced by different factors: methods used for isolation, cell culture medium used for differentiation, and agents used for enhancing osteogenic differentiation ability, FGF-1, BMP-2, BMP7 or BMP9 [80-82]. In vitro, osteogenic differentiation is usually induced using DMEM cell culture media supplemented with $10 \%$ of fetal bovine serum and a mixture of dexamethasone, ascorbic acid and $\beta$-glycerophosphate for a period of 21 days. Dexamethasone induces the expression of Runx2 mediated by $\beta$-catenin activation, ascorbic acid acts as a cofactor for proline- and lysine-hydroxylases that have a role in collagen synthesis, and $\beta$-glycerophosphate serves as a phosphate source for bone mineralization and induces osteogenic genes. Signaling pathways involved in osteoblast differentiation are that of ERK2 that activates Runx2, JNK/MAPK that is involved in downstream transduction of signals from BMP-2 [83], AMPK activated by adiponectin [75] and a very important role has been attributed to TGF- $\beta$ /SMAD pathway [84], whose activation leads to increased extracellular calcium deposition, increased alkaline phosphatase (ALP) production and increased expression of osteogenic genes as Runx2, ALP and osteocalcin [85]. In addition, some exosomal microRNAs have been proved to have a role in bone differentiation, acting as regulators of the balance between adipogenic and osteogenic differentiation in human ADSCs.

The process of chondrogenic differentiation of MSCs in vitro is usually performed with pellet or aggregate culture system, with DMEM high glucose media supplemented with FBS and antibiotics and addition of factors as TGF $\beta$, BMP and/or IGF (reviewed by Boeuf and Richter [86]; Somoza et al., [87]). Chondrocytes generated from MSCs expressed classical genes/proteins as native chondrocytes, e.g., type II collagen and aggrecan. However, it is also possible to identify hypertrophy-associated genes, as type $\mathrm{X}$ collagen, ALP and MMPs [87]. The data analysis also demonstrated that MSCs during chondrogenesis express classical markers of hyaline cartilage as aggrecan, SOX9, COL2 and others, but also express COL10, Runx2, ALPL, and MMP13 which are present in hypertrophic cartilage.

Subcutaneous ADSCs can differentiate into endothelial cells in vitro. Different subpopulations of cells from subcutaneous SVF, CD13 ${ }^{+} \mathrm{CD} 34^{+}[88], \mathrm{CD} 34^{+} \mathrm{CD} 31^{-}, \mathrm{Flk}^{-1}{ }^{+}$[89], and CD31- CD34- ${ }^{-} \mathrm{c}^{-k i t^{-}}$[88], have been shown to form vessel-like structures by applying matrigel-plug assay subcutaneously in mice. Two studies confirmed that phosphatidylinositol 3-kinase (PI3K) is a key signalling pathway in the process of ADSC differentiation toward endothelial cells [90,91].

ADSC s could also differentiate into smooth muscle cells [92,93], with TGF- $\beta 1 /$ Smad pathway activation having an important role [94].

ADSCs can differentiate to cardiomyocytes as well. Studies done by Planat-Bénard and collaborators revealed that ADSCs can be differentiated into cardiomyocyte-like cells [95] and, when these cells were injected in rats with a model of chronic myocardial infarction [96] and in nonhuman primates [97], they significantly improved the heart function.

Not only subcutaneous ADSCs have beneficial effect on improving vascular and cardiac function, Madonna and collaborators described that visceral (periepididymal and omental) ADSCs isolated from mice, cultured in methylcellulose medium, could spontaneously undergo neovascularization differentiation, forming $\mathrm{CD} 31^{+} \mathrm{CD} 34^{+}$tube-like structures [98]. Other studies have shown that $\mathrm{KDR}^{+} \mathrm{CD} 34^{-} \mathrm{CD} 31^{-}$ADSCs from human visceral adipose tissue or from murine visceral depot, 
intravenously or intramuscularly injected in mice with femoral artery ligation, enhanced capillary density and Doppler tissue perfusion scores $[90,99]$.

ADSCs isolated from cardiac tissue were prone to differentiate more into cardiovascular cells as compared with ADSCs from other sources [100]. On the other hand there are studies that have shown that epicardial ADSCs have higher cardiomyogenic potential than pericardial ADSCs [101], the latter having a better cardiac reparative activity than subcutaneous ADSCs, being able to differentiate toward myogenic lineage and supporting vasculogenesis. The cardioprotective effects of epicardial ADSCs have not been reproduced in a genetic model of obese hyperlipidemic and type- 2 diabetic rat.

\section{Extracellular Vesicles from Adipose Tissue Stem Cells}

\subsection{Classification and Molecular Properties of Adipose Tissue Extracellular Vesicles}

There is no consensus on specific markers of EV subtypes, such as endosomal origin exosomes (small EVs) and plasma membrane-derived ectosomes (microparticles/large EVs), therefore assigning EVs to a particular biogenesis pathway remains very difficult. Due to an increased interest in the EVs field and of higher number of published papers working with these EV subtypes, whose size and amount often make them difficult to obtain as relatively pure preparations, and to characterize properly, an improved guideline have been published in order to help scientists to make strong conclusions on the involvement of specific populations of EVs in physiological or pathological condition. A list of minimal information for studies of EVs (MISEV2018) was provided, covering EV separation/isolation, characterization, and functional studies. This updated ISEV statement reflects an improved understanding in EV biology, which has resulted in a consensus to promote meaningful changes to nomenclature and experimental approach. MISEV2018 guidelines advise the authors to use operational terms for EV subtypes that refer to (a) physical characteristics of EVs, such as size (small EVs (sEVs) and medium/large EVs (m/lEVs), with ranges defined, for instance, respectively, $<100 \mathrm{~nm}$ or $<200 \mathrm{~nm}$ [small], or $>200 \mathrm{~nm}$ [large and/or medium]) or density (low, middle, high, with each range defined); (b) biochemical composition $\left(\mathrm{CD}^{+} / \mathrm{CD} 81^{+}\right.$-EVs, Annexin A5-stained EVs, etc.); or (c) descriptions of conditions or cell of origin (podocyte EVs, hypoxic EVs, large oncosomes, apoptotic bodies) [102].

Considering the fat type and location, adipose tissue-derived EVs can be divided into: EVs secreted from subcutaneous or visceral fat and EVs secreted from WAT or BAT.

Molecular properties of adipose tissue EVs rest on their composition in lipids, proteins, and nucleic acids. Basically, the biomolecular content of EVs is similar to that of the source cell, any differences in adipose tissue-derived EVs composition resting on the content variability of the original fat cell type.

Adipose tissue EV release has been widely studied in explants from both adipose visceral and subcutaneous tissues $[103,104]$, as well as in in vitro differentiated adipocytes and in adipose tissue stem cells (ADSCs) [103]. However, most of the in vitro studies used the murine 3T3-L1 pre-adipocyte cell line differentiated to mature adipocytes and only a few used human adipocytes and adipose tissue extracts [105].

Analyses of microRNA (miRNA) profiles, showed that adipocyte-derived small EVs exhibit abundant miRNA content, many of which are up-regulated, such as miR-103, miR-146b, miR-148a [106-108]. Considering the length of adipogenesis induction, 3T3-L1 small EVs, registered a time dependent increment of adipogenesis-related gene transcripts expression, peroxisome proliferator-activated receptor $\gamma 2$ (PPAR $\gamma 2$ ), adiponectin and leptin [109]. Therefore, EVs from adipogenic induced 3T3-L1 cells, doubled adiponectin content, while fatty acid-binding protein 4 (FABP-4) and preadipocyte factor 1 (PREF-1) levels decreased [105]. Adiponectin, as well as a small amount of resistin were found also in small EVs from serum [110]. After adipogenesis, the lipid composition of EVs was also enriched in phosphatidiyl serine and arahidonic acid and in long chain omega-3 fatty acid decosahexaenoic acid [111]. Protein marker expression of CD9, CD36, TSG101 and Alix remained unchanged, after 3T3-L1 cell differentiation [105]. In normoxic and hypoxic conditions, 231 proteins were identified in 3T3-L1 small EVs, including enzymes involved in 
"de novo" lipogenesis, mostly when the hypoxic environment induced by adipocyte hypertrophy was mimicked [112]. Moreover, besides adipocyte specific proteins, several immunomodulatory proteins, such as tumor necrosis alpha (TNF- $\alpha$ ), macrophage-colony-stimulating factor (MCSF) and retinol binding protein4 (RBP-4), have been reported within the small EVs [103].

Human adipose tissue isolated ADSCs release small EVs that have been shown to contain small RNA species like miRNAs, small nucleolar RNAs (snoRNAs) and mostly transfer RNAs (tRNAs) [113]. Protein secretory profile of ADSCs is considered almost specific to each person, thus forming a heterogeneous population of cells that may produce equivalent EVs [114].

Differentiated human adipocytes-derived EV content is characterized by adipose specific markers FABP-4 as well as adiponectin and by a number of inflammatory adipokines, including macrophage migration inhibitory factor (MIF), TNF $\alpha$, MCSF, and RBP-4 [103]. Regarding the adipokine profile, visceral adipose tissue EVs have a significantly higher concentration of interleukin -6 (IL-6), MIF, and monocyte chemoattractant protein-1 (MCP-1) compared to those from subcutaneous adipose tissue. The content of EVs produced by both subcutaneous and visceral adipose tissue is also rich in adiponectin. In contrast to adiponectin-negative EVs produced mainly by stromal cells, adiponectin-positive EVs are produced exclusively by adipocytes.

Since the release of small EVs by BAT is increased after cAMP treatment, down regulation of specific marker miR-92a was also observed in both murine and human small EVs after cold exposure-dependent cAMP activation (Chen et al., 2016).

\subsection{Physiological Functions of Adipose Tissue Extracellular Vesicles}

Adipocyte released EVs influence the vascular health of the adipose tissue, being important means of vascular homeostasis regulation by neovascularization and angiogenesis [105], ADSC small EVs promoting vascular endothelial cell migration and proliferation and stimulating neo-vessel formation $[115,116]$.

Adipocyte-derived EVs (including large EVs and small EVs) may function as adipokines contributing to adipose tissue homeostasis or dysfunction. An important role of EVs isolated from adipose tissue is their capacity to mediate the endocrine connection between maternal adipose tissue and fetal growth, being unfortunately also responsible for fetal overgrowth [117]. Since adipocyte-derived EVs contain large amount of adiponectin, a crucial adipokine for glucose and lipid metabolism, also involved in fatty acid oxidation and insulin sensitivity [118], small EVs through their rich adiponectin content may be involved in distant cell metabolism.

Adipocyte derived EVs have also an important role in paracrine regulation of adipocyte metabolism [105]. Microvesicles and exosomes released by adipocytes containing glycosylphosphatidylinositol (GPI)-anchored proteins, CD73 and Gcel have role in esterification and in lipolysis inhibition [119] the small EVs may be effective players in adipocyte intercommunication [120].

The paracrine cross talk between adipocytes and macrophages is also regulated by adipose tissue-derived EVs. When primary monocytes differentiate into macrophages, the most effective EVs were adiponectin-positive and visceral ones compared to adiponectin-negative and subcutaneous EVs [103]. Moreover, the exposure of hepatocytes to subcutaneous and visceral adipose tissue-derived EVs led to a negative association between Akt signaling and glucose-6-phosphatase gene expression [103]. There is evidence of adipocyte-derived EV communication with the immune cells as well as their influence on whole body. EVs are implicated in regulation of hepatic insulin signalling and immunity as shown in vitro by their ability to reduce the proliferation rate of stimulated Tlymphocytes and by controlling monocyte to macrophage differentiation. 


\section{Pathobiological Significance of Extracellular Vesicles from Adipose Tissue Stem Cells in Diabetes and Associated Cardiovascular Disease}

\subsection{Extracellular Vesicles from Adipose Tissue Stem Cells as Diagnostic Biomarkers}

Biomarkers have a notable role in the prediction, diagnosis, and assessment of the therapeutic success in common multifactorial metabolic diseases, such as T2DM and obesity. Numerous studies have revealed that EVs are significant tools for biomarker discovery in early detection, due to their content that can be transferred, protected from degradation, from organs, tissues, and cells into body fluids. For instance, EVs released into the plasma and urine are considered specific biomarkers for the pathogenesis of T2DM [121].

The adipose tissue, among other sources as pancreatic islets (particularly $\beta$-cells), liver, skeletal muscle, vascular endothelial cells, and tissue and plasma macrophages are recognized candidates for relevant EVs.

Adipocyte hypertrophy and hyperplasia are both involved in the significant increase in adipose tissue mass in obese and T2DM patients [121]. Adipocyte hypertrophy has also been associated with the elevated production and release of EVs, characterized by the expression of perilipin A [122,123]. Perilipin A was identify to be a plausible biomarker of circulating EVs originating from the adipose tissue and a feasible target for novel diagnostics development for assessment of obesity-related adipocyte dysfunction and metabolic complications $[122,123]$. Furthermore, it has been shown that in obesity, plasma EVs contain high amount of cystatin C and CD14, that have been correlated with high risk for myocardial infarction, vascular disease mortality and subsequent vascular events, in patients with vascular diseases [124]. The expression of cystatin C in plasma EVs was positively associated with reduced systemic inflammation, diminished HDL-cholesterol levels and metabolic syndrome, while expression of CD14 was negatively related to adipose tissue abundance, dyslipidaemia and decreased risk for the T2DM development [125]. Interestingly, the generation of these two proteins was associated with development of cardiovascular complications. Cystatin C and CD14 expression was reported to be pronounced in adipose tissue, suggesting a potential contribution of the adipose tissue-derived EVs to the advance of metabolic complications of obesity [126]. Moreover, in obesity, adipose tissue develops resistance to insulin-mediated suppression of lipolysis which enhances the release of small EVs enriched in adipose fatty acid binding protein (aP2), leading to amplified liver glucose output and diabetes [127]. Interestingly, it has been indicated that ADSCs from the subcutaneous depots of obese subjects have lower expression levels of stem cell markers, such as octamer-binding transcription factor 4 (Oct4), Sall4, SRY-box transcription factor 15 (Sox15), Kruppel-like factor 4 (KLF4), and they also have a higher expression of the stem cell marker B cell-specific moloney murine leukemia virus integration site 1 (Bmi-1), compared with ADSCs derived from subcutaneous depots of lean donors [128]. In contrast, the same study showed that ADSCs derived from omental depots of obese subjects have greater expressions of Oct4, Sall4, Sox15, KLF4 and BMI1 compared to omental depots of the lean donors. In obese patients, the removal of large volume of adipose tissue by liposuction improves general heath and reduces leptin, increases adiponectin plasma levels and improves the inflammatory status [129] as result of decreasing the whole body fat mass containing both pathological adipocytes and inflammatory EVs from adipocytes and also ADSCs. On the other hand, liposuction-subjected normal weight patients show no significant changes or slight improvements in these metabolic parameters due to the removal of only small quantities of adipose tissue [130]. These findings suggest that obesity changes the adipose stem cell niche and its EVs output and is dependent on the depot-specific source of the adipose tissue stem cells.

Besides, it was shown that EVs released from cultured 3T3-L1 adipocytes contain about 140 miRNAs specific to the adipocytes. These adipocyte-derived EVs also harbor mRNAs coding for adiponectin, resistin and $\operatorname{PPAR} \gamma$, that can be transported into cultured macrophages inducing angiogenesis [121]. In obesity, elevated levels of miR-222, a negative regulator of insulin sensitivity in adipocytes, were found both in adipose tissue and in circulating small EVs [131]. In pre-adipocytes from obese 
subjects, several miRNAs were modified compared with lean subjects, miR-221, miR-125b, miR-34a and miR-100 were up-regulated while miR-130b, miR210 and miR-185 were down-regulated [132]. Thus, miRNAs associated with EVs derived from adipocytes, like those derived from vascular cells and macrophages, seem to reflect the functional state of the adipose tissue and may be useful for following the development of obesity and may be considered markers for diagnostic. See Figure 1 for a summary of the proposed markers of disease, disease mediating molecules and therapeutic targets found in ADSC-derived EVs.

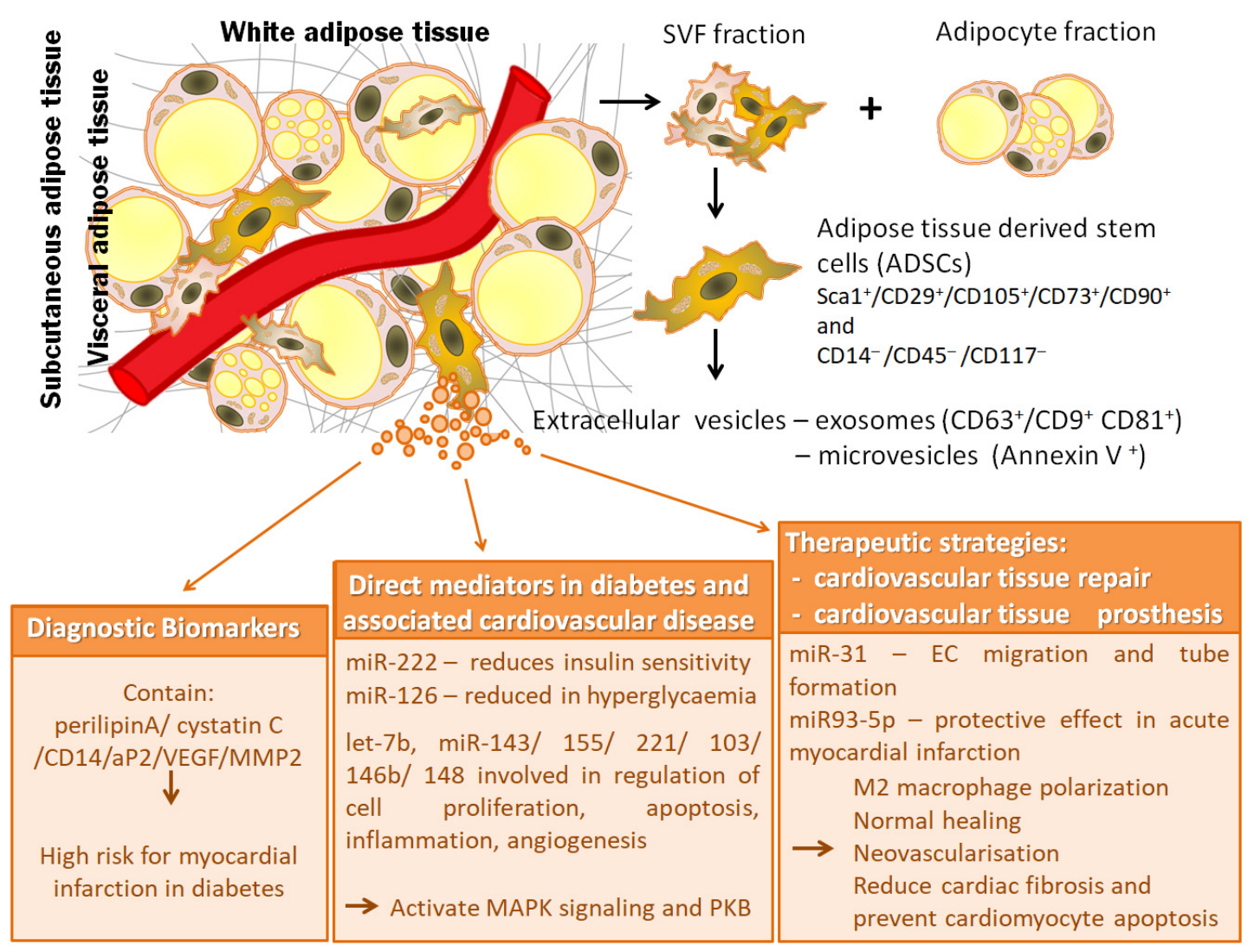

Figure 1. Relevance of extracellular vesicles from adipose tissue stem cells in pathophysiology of diabetes and associated cardiovascular disease: extracellular vesicles as diagnostic biomarkers, direct mediators and therapeutic strategies.

The study of biomarkers from adipose tissue-derived EVs for cardiovascular diseases is still in its beginning and current available data from human clinical trials showing promising candidate marker molecules on EVs are summarized in Table 1 below. The EV-based biomarkers could provide essential diagnostic and prognostic values for better treatment of patients.

Currently, no definitive marker of adipocyte-derived EVs has yet been decided and no consensus was established regarding the characteristic EV cargo. This makes it difficult to interpret findings on circulating EVs in obesity and metabolic diseases as well as in type 2 diabetes [133]. The miRNAs carried by EVs secreted by adipose tissue could provide new diagnostics biomarkers to distinguish metabolically healthy versus metabolically unhealthy obesity, and new approaches to deliver miRNAs that target genes in the liver and other tissues for metabolic syndrome management. 
Table 1. Clinical studies on ADSC-derived EVs and adipocyte-derived EVs as markers in cardiovascular disease.

\begin{tabular}{|c|c|c|c|c|}
\hline $\begin{array}{l}\text { Condition/ } \\
\text { Disease }\end{array}$ & Patients & Extracellular Vesicles & Main Findings & Study \\
\hline Obesity & $\begin{array}{l}14 \text { obese patients, w/o diabetes, } \\
\text { not on medication for metabolic } \\
\text { syndrome alleviation, vs. } 23 \text { lean } \\
\text { control subjects }\end{array}$ & plasma EVs & $\begin{array}{l}\text { EVs are increased in the circulation of } \\
\text { obese subjects } \\
\text { - circulating EVs numbers correlate with } \\
\text { insulin resistance } \\
\text { - } \quad \text { perilipin A is a biomarker for circulating } \\
\text { EVs from stressed adipocytes. }\end{array}$ & Eguchi A, et al., 2016 [123] \\
\hline $\begin{array}{l}\text { Cardio- vascular } \\
\text { diseases }\end{array}$ & $\begin{array}{l}1060 \text { patients from a prospective } \\
\text { study cohort }\end{array}$ & $\begin{array}{l}\text { plasma medium/ } \\
\text { large EVs }\end{array}$ & $\begin{array}{l}\text { - Cystatin C, Serpin F2, and CD14 levels in } \\
\text { plasma medium/large EVs are correlated } \\
\text { with MI incidence, vascular mortality and } \\
\text { all-cause mortality. } \\
\text { CD14 levels were further correlated with } \\
\text { the occurrence of ischemic stroke. }\end{array}$ & Kanhai DA, et al., 2013 [124] \\
\hline $\begin{array}{l}\text { Obesity and Cardio- } \\
\text { vascular diseases }\end{array}$ & $\begin{array}{l}1012 \text { patients with clinically } \\
\text { manifest vascular disease }\end{array}$ & plasma EVs & $\begin{array}{l}\text { - Cystatin C levels are positively related to } \\
\text { metabolic complications of obesity } \\
\text { CD14 are negatively related to metabolic } \\
\text { complications of obesity. }\end{array}$ & Kranendonk ME, et al., 2014 [125] \\
\hline Obesity and diabetes & $\begin{array}{ll}- & 6 \text { non-obese subjects } \\
- & 9 \text { obese with T2DM subjects } \\
- & 13 \text { obese without T2DM subjects }\end{array}$ & $\begin{array}{l}\text { pre-adipocytes from sub- } \\
\text { cutaneous fat and, by extension, } \\
\text { EVs from pre- adipocytes }\end{array}$ & $\begin{array}{l}\text { miR-221, miR- } 125 \mathrm{~b}, \mathrm{miR}-34 \mathrm{a} \text { and } \mathrm{miR}-100 \\
\text { were up-regulated in obese subjects } \\
\text { miR-130b, miR210 and miR-185 were } \\
\text { down-regulated in obese subjects }\end{array}$ & Ortega FJ, et al., 2010 [132] \\
\hline
\end{tabular}




\subsection{Pathological Roles and Responsible Mechanisms of Adipose Tissue Extracellular Vesicles}

There is growing evidence that adipose tissue is a major contributor of circulating miRNAs and that miRNAs carried by adipocytes-derived EVs, may possess hormone-like functions, communicating with other tissues to coordinate metabolic homeostasis and energy balance [131]. When these systems are disturbed, they may also participate to the pathophysiology of metabolic diseases, such as obesity, lipodystrophy, type 2 diabetes, and metabolic syndrome, and they may also contribute to insulin resistance in these diseases [131].

Despite the fact that there are many reports regarding the importance of adipose tissue-derived EVs in development of metabolic diseases, the role of EVs from ADSCs in obesity and related pathological conditions remains unclear.

Some studies have shown that ADSC-derived EVs might increase insulin sensitivity through their ability to decrease inflammation [134]. Recently, it was demonstrated that ADSC-derived large EVs from normal subjects are rich in miRNAs, including two members of the let-7 family, with role in angiogenesis [135]. These ADSC-derived large EVs can promote the migration and invasion abilities of endothelial cells, suggesting their pro-angiogenetic potential. These data are in agreement with a previous study indicating that miR-31 carried by ADSC-derived large EVs contributes to the migration and tube formation of endothelial cells by targeting and suppressing factor-inhibiting hypoxia-inducible factor-1 Also, it has been reported that adipocyte-derived large EVs carry a subset of miRNAs, such as let-7b, miR-143, miR-155, and miR-221 that are involved in the control of cell proliferation, apoptosis, inflammation and angiogenesis in adipose and vascular tissues [109]. Other miRNAs contained by adipocyte-derived large EVs are miR-103 and miR-146b/148. Moreover, it was reported that circulating adipose-derived small EVs transport miR-99b, that is involved in regulation of liver fibroblast growth factor 21 (FGF21), contributing in this way to the control of metabolic homeostasis, as well as to systemic insulin resistance [136]. These data suggest the positive role of healthy ADSC-derived EVs on the metabolic homeostasis.

In contrary, there are data that indicate potential pathogenic role for ADSC-derived EVs which act at distance in various metabolic diseases. In this context, studies have shown that EVs from obese ADSCs, either from subcutaneous or from visceral depots, contain reduced levels of vascular endothelial growth factor (VEGF) and matrix metalloproteinase-2 (MMP-2), compared to those derived from the same compartments in non-obese individuals, suggesting that they may have lowered pro-angiogenic potential [133]. Moreover, it has been noticed that small EVs secreted by obese ADSCs contain impaired levels of miR-126, which are damaged by the additionally hyperglycaemic milieu [137].

In metabolic syndrome, it has been demonstrated that EVs derived from porcine ADSCs contain high levels of some miRNAs, including miR-146a-3p, miR-30c-1-3p, miR-7, miR-148a-5p, miR-374a-3p, miR-23a, miR-132, miR-129b [138]. These miRNAs target transcription factors, as well as genes, implicated in the development of metabolic syndrome and its complications, including validated transcriptional targets of AP1 family members Fra1 and Fra2, Class A/1 (Rhodopsin-like receptors), and Peptide ligand-binding receptors [138]. Additionally, the same authors found that, in metabolic syndrome, porcine ADSCs contain seven upregulated miRNAs, including miR-196a, miR-301, miR-27b, miR-7a, miR-7c, and miR-7e, miR-425 and three downregulated miRNAs, miR-99a, miR-708, and miR-148a, which regulate 35 senescence-associated genes, particularly involved in MAPK signaling, suggesting that these miRNAs may modulate ADSC senescence [139]. The evaluation of these miRNAs in ADSCs-derived EVs could be useful in following the ADSC senescence in metabolic diseases. Interestingly, it has been reported that small EVs derived from ADSCs from omental depots of obese patients are enriched in lincRNA-VLDLR, and also have a higher expression of metastasis-associated lung adenocarcinoma transcript 1 (MALAT1), compared to small derived from ADSCs of omental depots of lean donor [128]. These specific long noncoding RNAs (lncRNAs) can be transferred to recipient cells to regulate gene expression. Thus, it was found that internalization of ADSC-derived small EVs by human dermal fibroblasts induced increased expression of MALAT1, which is involved in the modulation of several molecular signaling pathways and affects proliferation, 
cell cycle, migration, and angiogenesis $[140,141]$. Some evidence shows that ADSC-derived small EVs activate the protein kinase B (PKB, also known as Akt) and extracellular signal-regulated kinase (ERK) signaling pathways, which are involved in the proliferation, migration, and tube formation of endothelial cells. Moreover, it have been demonstrated that ADSC-derived small EVs play an inhibitory role in cell apoptosis by transferring and regulating proteins and miRNAs [142].

Consequently, although the data presented above suggests that the profiles of EVs derived from adipose tissue change in obesity and metabolic disease, it is not yet clear whether EVs could be used only as markers of disease or if they also play an important functional role in inter-tissue communication.

\section{Adipose Tissue Stem Cell-Derived Extracellular Vesicle Based Therapeutics for Diabetes and Associated Cardiovascular Disease}

\subsection{Effects of Adipose Tissue Extracellular Vesicles in Cardiovascular Tissue Repair}

Nonalcoholic fatty liver disease (NAFLD), and especially NAFLD associated with liver fibrosis, is a known risk factor for cardiovascular disease $[143,144]$. The EVs shed from visceral ADSCs of obese subjects integrated in cultured hepatocytes and hepatic stellate cells were shown to dysregulate the transforming growth factor $\beta$ (TGF $\beta$ ) signaling pathway compared to EVs from lean subjects, leading in obesity-associated T2DM to expression profiles similar to those in NAFLD [104]. However, EVs derived from MSCs were shown to alleviate tetrachloride induced liver fibrosis in a mouse model [145] and, in a similar model, ADSC-derived EVs enriched with miR-181-5p reduced liver fibrosis even more efficiently compared to native ADSC-derived EVs, by inhibiting the STAT3/Bcl-2/Beclin 1 pathway [146]. Another study suggests that EVs from adipose tissue can contribute to systemic insulin resistance with effects on both hepatocytes and skeletal muscle cells. In hepatocytes, the studied EVs inhibited insulin-induced Akt phosphorylation, while in myotubes they exerted either an insulin inhibiting or stimulating effect, depending on the subject from which EVs were obtained. This study also found that the number of subcutaneous EVs was reduced in obesity and that omental EVs can predict liver dysfunction as indicated by elevated liver enzymes [147]. As insulin resistance is a known risk factor for cardiovascular disease [148], EVs from ADSC might play roles in both the pathogenesis and prevention of adverse cardiovascular outcomes. Supporting this claim, a high-fat diet mouse model, intraperitoneally administered ADSC-derived small EVs led to improvements in glucose tolerance and insulin sensitivity, decreased the serum levels of triglycerides and total cholesterol and alleviated the hepatic steatosis observed in the control group [134].

The ADSC-derived EVs play roles not only in alleviating known risk factors of cardiovascular disease, but it also has been shown that they could be useful for therapeutic approach of acute cardiovascular events. In vitro, ADSC-derived EVs prevented cardiomyocyte apoptosis induced by oxidative stress, and in vivo animal models of cardiac infarction, intravenous administrated ADSC-derived EVs improved echocardiographic and hemodynamic outcomes by leading M2 macrophage polarization and immune cell trafficking, as shown by the activation of the S1P/SK1/S1PR1 pathway [149], and reduced the cardiac fibrosis and pro-inflammatory cytokine levels while promoting angiogenesis, with miR-126-enriched EVs having a larger effect [150]. Additionally, in a different study, miR-93-5p-entiched EVs showed an even greater protective effect on acute myocardial infarction-induced myocardial damage than unmodified ADSC derived EVs, by reducing Atg7-mediated autophagy and suppressing TLR4 [151].

The angiogenesis-inducing activity of ADSC-derived EVs was also shown to serve therapeutic functions in the wound healing of healthy or diabetic animals [152,153], this effects being at least partly mediated by PI3K/Akt activation in fibroblasts leading to increased proliferation, migration, and collagen synthesis [154]. Moreover, EVs released after stimulation with hydrogen peroxide $\left(\mathrm{H}_{2} \mathrm{O}_{2}\right)$ of ADSCs seem to promote neovascularization and inflammation and reduce apoptosis after ischemic-reperfusion injury [155] pointing to the importance of the cell culturing conditions.

ADSCs intravenously administrated to atherosclerotic rats lowered VEGF, ET-1, VCAM-1, and ICAM-1 markers of endothelial activation, CRP, IL-6, and TNF $\alpha$ inflammation markers, improved the lipidic 
profile and reduced the size of atherosclerotic plaques [156]. However, the observed improvements are likely a cumulative of ADSC differentiation and subsequent tissue repair and paracrine secretion of EVs and other soluble factors. An in vitro study aiming to distinguish ADSC-derived EV effects from differentiation of ADSCs to endothelial cells showed that EVs alone are able to decrease the apoptosis of endothelial cells, presumably by the reduction of miR-324-5p expression, a putative marker and effector of atherosclerosis [157].

Figure 2 summarizes the reported actions of ADSC-derived EVs in different organs and body compartments.

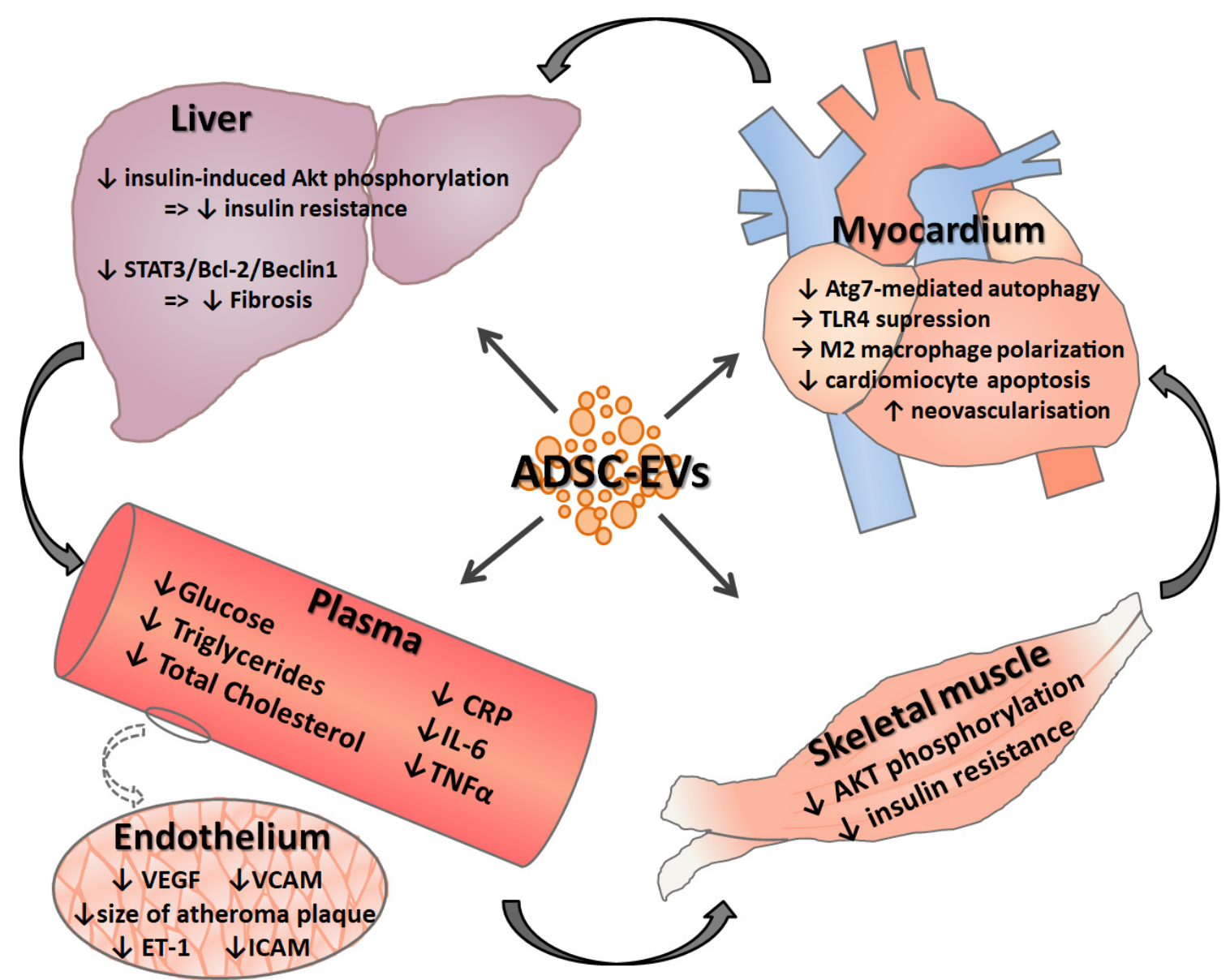

Figure 2. Effects of extracellular vesicles from adipose tissue stem cells on different organs involved in the pathology of diabetes and associated cardiovascular disease.

\subsection{Potential Use of Adipose Tissue-Derived Stem Cells and Extracellular Vesicles Generated by Them in Cardiovascular Tissue Prostheses}

ADSCs could be used in the production of vessel prosthesis due to their ability of differentiating in both endothelial as well as smooth muscle cells. For this purpose, multiple stimuli are to be employed: VEGF and physiological shear stress are enough to differentiate human ADSCs seeded on collagen or acellular valve matrices into endothelial cells [158], while for the differentiation in smooth muscle cells, uniaxial mechanical strain at a frequency of $1 \mathrm{~Hz}$, as well as TGF- $\beta 1$ stimulation were successfully employed [159]. A similar approach was used to produce from a polyglycolic acid mesh and ADSCs a small diameter elastic blood vessel wall with contractile function [160]. Moreover, ADSCs incorporated in bioprinted scaffolds presented good viability, proliferation and differentiation in both endothelial cells and smooth muscle cells [161]. Different materials were used for the scaffold, such as polycaprolactone [162] and in the case of synthetic scaffolds use, additional collagen I, III or fibronectin coating helps in ADSCs retention [163]. 
It was also noted that co-incubation of smooth muscle cells with ADSCs pre-differentiated towards smooth muscle cells presents better functional traits compared to smooth muscle cells monoculture due to the initial paracrine function of ADSCs and their latter differentiation into fully functional smooth muscle cells. In experiments using static repopulation of acellular valves, ADSCs migrated only superficially [164], highlighting the need of mechanical stimulation for ADSCs migration and differentiation.

Cell therapy using ADSCs is not only sought for the differentiation capabilities of these cells but also for their paracrine function with growth hormones, cytokines and small EVs as secreted factors. As a way to retain ADSCs at their intended site of action for them to exert their paracrine actions, ADSCs-carrier sheets were developed and showed promising results in the treatment of myocardial infarction such as increased survival post myocardial infarction [165-167] in animal models.

ADSCs incorporation in macroencapsulation devices was also used to raise the biocompatibility of the biomaterials employed-polytetrafluoroethylene and polyethylene terephthalate-by modulating the immune responses, reducing fibrosis and promoting angiogenesis. This effect is due to the paracrine function of ADSCs as the cells themselves were restricted to the inside of the device [168].

\section{Conclusions and Perspectives}

There are numerous studies on EVs secreted from ADSCs, but few of these are original research that has investigated their involvement in diabetes and associated cardiovascular disease. It is well known that, ADSC-derived EVs seem to have potential roles in different physiological and pathophysiological situations, both as a direct effector to promote or prevent pathogenesis and as a delivery system to target miRNAs to cells. Besides their potential as markers for early diagnosis of the disease, ADSC-derived EVs were found to exert effects on angiogenesis, cell survival and apoptosis, inflammation, tissue regeneration, and reduction of disease pathology.

This review offers a systematic presentation on EVs secreted from ADSCs and their pathobiological significance in diabetes and associated cardiovascular disease. Additionally, responsible mechanisms and their determined roles on cardiovascular tissue repair and prostheses are discussed. It has thus been shown that adipose tissue is a real source of stem cells, and EVs produced by ADSCs appear to have potential roles in diabetes and cardiovascular pathology, both as biomarkers and direct contributors as well as a therapeutic option.

Future investigations are required to identify the ADSC-derived EV signature, causally involved in the pathogenesis of metabolic disorders, such as diabetes and associated cardiovascular disease, and those that reflect the temporal and individual disease states.

Although the results of the studies show that EV profile changes in diabetes and cardiovascular disorders, it cannot be stated with certainty that EVs are only a marker of the disease or if they actively participate in the progression of pathological processes or, on the contrary, in their regression.

Given ADSC-derived EVs potential for nanoparticle-based disease therapy, future research should consider these therapeutic abilities especially in pathology of cardiovascular diseases in diabetes. However, much more research is needed that pilot studies on patients be considered.

Author Contributions: Conceptualization, A.G.; writing-original draft preparation, A.C., A.F., N.A., M.N. and A.G.; writing-review and editing, A.G.; supervision, A.G.; funding acquisition, A.G. All authors have read and agreed to the published version of the manuscript.

Funding: This work was supported by a grant from the Competitiveness Operational Program 2014-2020, Targeted therapies for aortic valve disease in diabetes, THERAVALDIS, ID P_37_298, MySMIS code: 104362, contract number 115/13.09.2016.

Conflicts of Interest: The authors declare no conflict of interest. 


\section{Abbreviations}

\begin{tabular}{|c|c|}
\hline ADSCs & Adipose tissue-derived stem cells \\
\hline EVs & extracellular vesicles \\
\hline WAT & white adipose tissue \\
\hline BAT & brown adipose tissue \\
\hline SVF & stromal vascular fraction \\
\hline MSCs & mesenchymal stem cells \\
\hline $\operatorname{PDGFR} \alpha$ & platelet-derived growth factor receptor alpha \\
\hline PDGFR $\beta$ & platelet-derived growth factor receptor beta \\
\hline Wt1 & Wilms' tumor 1 \\
\hline scRNAseq & single cell RNA sequencing \\
\hline FACS & fluorescent activated cell sorting \\
\hline ISCT & International Society for Cellular Therapy \\
\hline PI3K & phosphatidylinositol 3-kinase \\
\hline miRNA & microRNA \\
\hline PPAR $\gamma 2$ & peroxisome proliferator-activated receptor $\gamma 2$ \\
\hline TNF- $\alpha$ & tumor necrosis alpha \\
\hline MCSF & macrophage-colony-stimulating factor \\
\hline RBP-4 & retinol binding protein 4 \\
\hline snoRNAs & small nucleolar RNAs \\
\hline tRNAs & transfer RNAs \\
\hline MIF & macrophage migration inhibitory factor \\
\hline IL-6 & interleukin -6 \\
\hline MCP-1 & chemoattractant protein-1 \\
\hline FGF21 & fibroblast growth factor 21 \\
\hline VEGF & vascular endothelial growth factor \\
\hline MMP-2 & matrix metalloproteinase-2 \\
\hline $\operatorname{lncRNAs}$ & long noncoding RNAs \\
\hline PKB & protein kinase B \\
\hline ERK & extracellular signal-regulated kinase \\
\hline NAFLD & nonalcoholic fatty liver disease \\
\hline TGF $\beta$ & transforming growth factor $\beta$ \\
\hline T2DM & type 2 diabetes \\
\hline MISEV & minimal information for studies of extracellular vesicles \\
\hline
\end{tabular}

\section{References}

1. Wang, W.; Seale, P. Control of brown and beige fat development. Nat. Rev. Mol. Cell Biol. 2016, 17, 691-702. [CrossRef] [PubMed]

2. Silva, F.J.; Holt, D.J.; Vargas, V.; Yockman, J.; Boudina, S.; Atkinson, D.; Grainger, D.W.; Revelo, M.P.; Sherman, W.; Bull, D.A.; et al. Metabolically active human brown adipose tissue derived stem cells. Stem Cells 2014, 32, 572-581. [CrossRef]

3. Wang, S.; Yang, X. Inter-organ regulation of adipose tissue browning. Cell. Mol. Life Sci. 2017, 74, $1765-1776$. [CrossRef] [PubMed]

4. Rosenwald, M.; Perdikari, A.; Rulicke, T.; Wolfrum, C. Bi-directional interconversion of brite and white adipocytes. Nat. Cell Biol. 2013, 15, 659-667. [CrossRef] [PubMed]

5. Petrovic, N.; Walden, T.B.; Shabalina, I.G.; Timmons, J.A.; Cannon, B.; Nedergaard, J. Chronic peroxisome proliferator-activated receptor gamma (PPARgamma) activation of epididymally derived white adipocyte cultures reveals a population of thermogenically competent, UCP1-containing adipocytes molecularly distinct from classic brown adipocytes. J. Biol. Chem. 2010, 285, 7153-7164. [CrossRef] [PubMed]

6. Wu, J.; Jun, H.; McDermott, J.R. Formation and activation of thermogenic fat. Trends Genet. 2015, 31, $232-238$. [CrossRef] [PubMed]

7. Jeffery, E.; Church, C.D.; Holtrup, B.; Colman, L.; Rodeheffer, M.S. Rapid depot-specific activation of adipocyte precursor cells at the onset of obesity. Nat. Cell Biol. 2015, 17, 376-385. [CrossRef] 
8. Van Beek, L.; van Klinken, J.B.; Pronk, A.C.; van Dam, A.D.; Dirven, E.; Rensen, P.C.; Koning, F.; Willems van Dijk, K.; van Harmelen, V. The limited storage capacity of gonadal adipose tissue directs the development of metabolic disorders in male C57Bl/6J mice. Diabetologia 2015, 58, 1601-1609. [CrossRef]

9. Wang, Q.A.; Tao, C.; Gupta, R.K.; Scherer, P.E. Tracking adipogenesis during white adipose tissue development, expansion and regeneration. Nat. Med. 2013, 19, 1338-1344. [CrossRef]

10. Arner, E.; Westermark, P.O.; Spalding, K.L.; Britton, T.; Ryden, M.; Frisen, J.; Bernard, S.; Arner, P. Adipocyte turnover: Relevance to human adipose tissue morphology. Diabetes 2010, 59, 105-109. [CrossRef]

11. Lessard, J.; Laforest, S.; Pelletier, M.; Leboeuf, M.; Blackburn, L.; Tchernof, A. Low abdominal subcutaneous preadipocyte adipogenesis is associated with visceral obesity, visceral adipocyte hypertrophy, and a dysmetabolic state. Adipocyte 2014, 3, 197-205. [CrossRef]

12. Shao, M.; Vishvanath, L.; Busbuso, N.C.; Hepler, C.; Shan, B.; Sharma, A.X.; Chen, S.; Yu, X.; An, Y.A.; Zhu, Y.; et al. De novo adipocyte differentiation from Pdgfrbeta(+) preadipocytes protects against pathologic visceral adipose expansion in obesity. Nat. Commun. 2018, 9, 890. [CrossRef]

13. Longo, M.; Zatterale, F.; Naderi, J.; Parrillo, L.; Formisano, P.; Raciti, G.A.; Beguinot, F.; Miele, C. Adipose Tissue Dysfunction as Determinant of Obesity-Associated Metabolic Complications. Int. J. Mol. Sci. 2019, 20, 2358. [CrossRef]

14. Samuel, V.T.; Shulman, G.I. Mechanisms for insulin resistance: Common threads and missing links. Cell 2012, 148, 852-871. [CrossRef]

15. Russo, V.; Yu, C.; Belliveau, P.; Hamilton, A.; Flynn, L.E. Comparison of human adipose-derived stem cells isolated from subcutaneous, omental, and intrathoracic adipose tissue depots for regenerative applications. Stem Cells Transl. Med. 2014, 3, 206-217. [CrossRef]

16. Chi, C.; Wang, F.; Xiang, B.; Deng, J.; Liu, S.; Lin, H.Y.; Natarajan, K.; Li, G.; Wang, L.; Wang, J.; et al. Adipose-derived stem cells from both visceral and subcutaneous fat deposits significantly improve contractile function of infarcted rat hearts. Cell Transplant. 2015, 24, 2337-2351. [CrossRef]

17. Gherghiceanu, M.; Alexandru, N.; Magda, S.L.; Constantin, A.; Nemecz, M.; Filippi, A.; Ioghen, O.C.; Ceafalan, L.; Bojin, F.; Tanko, G.; et al. Part One: Extracellular Vesicles as Valuable Players in Diabetic Cardiovascular Diseases. In Extracellular Vesicles and Their Importance in Human Health; de Bona, A.G., Ed.; IntechOpen: London, UK, 2019.

18. Hulsmans, M.; Holvoet, P. MicroRNA-containing microvesicles regulating inflammation in association with atherosclerotic disease. Cardiovasc. Res. 2013, 100, 7-18. [CrossRef]

19. Martinez, M.C.; Andriantsitohaina, R. Extracellular Vesicles in Metabolic Syndrome. Circ. Res. 2017, 120, 1674-1686. [CrossRef]

20. Freeman, D.W.; Noren Hooten, N.; Eitan, E.; Green, J.; Mode, N.A.; Bodogai, M.; Zhang, Y.; Lehrmann, E.; Zonderman, A.B.; Biragyn, A.; et al. Altered Extracellular Vesicle Concentration, Cargo, and Function in Diabetes. Diabetes 2018, 67, 2377-2388. [CrossRef]

21. Lai, R.C.; Chen, T.S.; Lim, S.K. Mesenchymal stem cell exosome: A novel stem cell-based therapy for cardiovascular disease. Regen. Med. 2011, 6, 481-492. [CrossRef]

22. Bagno, L.; Hatzistergos, K.E.; Balkan, W.; Hare, J.M. Mesenchymal Stem Cell-Based Therapy for Cardiovascular Disease: Progress and Challenges. Mol. Ther. J. Am. Soc. Gene Ther. 2018, 26, 1610-1623. [CrossRef]

23. De Bari, C.; Roelofs, A.J. Stem cell-based therapeutic strategies for cartilage defects and osteoarthritis. Curr. Opin. Pharmacol. 2018, 40, 74-80. [CrossRef]

24. Vonk, L.A.; van Dooremalen, S.F.J.; Liv, N.; Klumperman, J.; Coffer, P.J.; Saris, D.B.F.; Lorenowicz, M.J. Mesenchymal Stromal/stem Cell-derived Extracellular Vesicles Promote Human Cartilage Regeneration In Vitro. Theranostics 2018, 8, 906-920. [CrossRef]

25. Grange, C.; Tritta, S.; Tapparo, M.; Cedrino, M.; Tetta, C.; Camussi, G.; Brizzi, M.F. Stem cell-derived extracellular vesicles inhibit and revert fibrosis progression in a mouse model of diabetic nephropathy. Sci. Rep. 2019, 9, 4468. [CrossRef]

26. Fujii, S.; Miura, Y.; Fujishiro, A.; Shindo, T.; Shimazu, Y.; Hirai, H.; Tahara, H.; Takaori-Kondo, A.; Ichinohe, T.; Maekawa, T. Graft-Versus-Host Disease Amelioration by Human Bone Marrow Mesenchymal Stromal/Stem Cell-Derived Extracellular Vesicles Is Associated with Peripheral Preservation of Naive T Cell Populations. Stem Cells 2018, 36, 434-445. [CrossRef] 
27. Lv, K.; Li, Q.; Zhang, L.; Wang, Y.; Zhong, Z.; Zhao, J.; Lin, X.; Wang, J.; Zhu, K.; Xiao, C.; et al. Incorporation of small extracellular vesicles in sodium alginate hydrogel as a novel therapeutic strategy for myocardial infarction. Theranostics 2019, 9, 7403-7416. [CrossRef]

28. Jha, V.; Garcia-Garcia, G.; Iseki, K.; Li, Z.; Naicker, S.; Plattner, B.; Saran, R.; Wang, A.Y.; Yang, C.W. Chronic kidney disease: Global dimension and perspectives. Lancet 2013, 382, 260-272. [CrossRef]

29. Barutta, F.; Tricarico, M.; Corbelli, A.; Annaratone, L.; Pinach, S.; Grimaldi, S.; Bruno, G.; Cimino, D.; Taverna, D.; Deregibus, M.C.; et al. Urinary exosomal microRNAs in incipient diabetic nephropathy. PLOS ONE 2013, 8, e73798. [CrossRef]

30. Delic, D.; Eisele, C.; Schmid, R.; Baum, P.; Wiech, F.; Gerl, M.; Zimdahl, H.; Pullen, S.S.; Urquhart, R. Urinary Exosomal miRNA Signature in Type II Diabetic Nephropathy Patients. PLoS ONE 2016, 11, e0150154. [CrossRef] [PubMed]

31. Ramezani, A.; Devaney, J.M.; Cohen, S.; Wing, M.R.; Scott, R.; Knoblach, S.; Singhal, R.; Howard, L.; Kopp, J.B.; Raj, D.S. Circulating and urinary microRNA profile in focal segmental glomerulosclerosis: A pilot study. Eur. J. Clin. Investig. 2015, 45, 394-404. [CrossRef]

32. Zuk, P.A.; Zhu, M.; Mizuno, H.; Huang, J.; Futrell, J.W.; Katz, A.J.; Benhaim, P.; Lorenz, H.P.; Hedrick, M.H. Multilineage cells from human adipose tissue: Implications for cell-based therapies. Tissue Eng. 2001, 7, 211-228. [CrossRef]

33. Gimble, J.M.; Katz, A.J.; Bunnell, B.A. Adipose-derived stem cells for regenerative medicine. Circ. Res. 2007, 100, 1249-1260. [CrossRef] [PubMed]

34. Zuk, P.A.; Zhu, M.; Ashjian, P.; De Ugarte, D.A.; Huang, J.I.; Mizuno, H.; Alfonso, Z.C.; Fraser, J.K.; Benhaim, P.; Hedrick, M.H. Human adipose tissue is a source of multipotent stem cells. Mol. Biol. Cell 2002, 13, 4279-4295. [CrossRef]

35. Fraser, J.K.; Wulur, I.; Alfonso, Z.; Hedrick, M.H. Fat tissue: An underappreciated source of stem cells for biotechnology. Trends Biotechnol. 2006, 24, 150-154. [CrossRef]

36. Chau, Y.Y.; Bandiera, R.; Serrels, A.; Martinez-Estrada, O.M.; Qing, W.; Lee, M.; Slight, J.; Thornburn, A.; Berry, R.; McHaffie, S.; et al. Visceral and subcutaneous fat have different origins and evidence supports a mesothelial source. Nat. Cell Biol. 2014, 16, 367-375. [CrossRef]

37. Scherberich, A.; Di Maggio, N.D.; McNagny, K.M. A familiar stranger: CD34 expression and putative functions in SVF cells of adipose tissue. World J. Stem Cells 2013, 5, 1-8. [CrossRef]

38. Peng, Q.; Alipour, H.; Porsborg, S.; Fink, T.; Zachar, V. Evolution of ASC Immunophenotypical Subsets During Expansion In Vitro. Int. J. Mol. Sci. 2020, 21, 1408. [CrossRef]

39. Traktuev, D.O.; Merfeld-Clauss, S.; Li, J.; Kolonin, M.; Arap, W.; Pasqualini, R.; Johnstone, B.H.; March, K.L. A population of multipotent $\mathrm{CD} 34$-positive adipose stromal cells share pericyte and mesenchymal surface markers, reside in a periendothelial location, and stabilize endothelial networks. Circ. Res. 2008, 102, 77-85. [CrossRef]

40. Berry, R.; Rodeheffer, M.S. Characterization of the adipocyte cellular lineage in vivo. Nat. Cell Biol. 2013, 15, 302-308. [CrossRef]

41. Rodeheffer, M.S.; Birsoy, K.; Friedman, J.M. Identification of white adipocyte progenitor cells in vivo. Cell 2008, 135, 240-249. [CrossRef]

42. Berry, D.C.; Jiang, Y.; Graff, J.M. Emerging Roles of Adipose Progenitor Cells in Tissue Development, Homeostasis, Expansion and Thermogenesis. Trends Endocrinol. Metab. 2016, 27, 574-585. [CrossRef] [PubMed]

43. Crisan, M.; Yap, S.; Casteilla, L.; Chen, C.W.; Corselli, M.; Park, T.S.; Andriolo, G.; Sun, B.; Zheng, B.; Zhang, L.; et al. A perivascular origin for mesenchymal stem cells in multiple human organs. Cell Stem Cell 2008, 3, 301-313. [CrossRef] [PubMed]

44. Gao, Z.; Daquinag, A.C.; Su, F.; Snyder, B.; Kolonin, M.G. PDGFRalpha/PDGFRbeta signaling balance modulates progenitor cell differentiation into white and beige adipocytes. Development 2018, 145. [CrossRef]

45. Lachaud, C.C.; Pezzolla, D.; Dominguez-Rodriguez, A.; Smani, T.; Soria, B.; Hmadcha, A. Functional vascular smooth muscle-like cells derived from adult mouse uterine mesothelial cells. PLoS ONE 2013, 8, e55181. [CrossRef]

46. Lansley, S.M.; Searles, R.G.; Hoi, A.; Thomas, C.; Moneta, H.; Herrick, S.E.; Thompson, P.J.; Newman, M.; Sterrett, G.F.; Prele, C.M.; et al. Mesothelial cell differentiation into osteoblast- and adipocyte-like cells. J. Cell Mol. Med. 2011, 15, 2095-2105. [CrossRef] 
47. Chau, Y.Y.; Brownstein, D.; Mjoseng, H.; Lee, W.C.; Buza-Vidas, N.; Nerlov, C.; Jacobsen, S.E.; Perry, P.; Berry, R.; Thornburn, A.; et al. Acute multiple organ failure in adult mice deleted for the developmental regulator Wt1. PLoS Genet. 2011, 7, e1002404. [CrossRef]

48. Sanchez-Gurmaches, J.; Hsiao, W.Y.; Guertin, D.A. Highly selective in vivo labeling of subcutaneous white adipocyte precursors with Prx1-Cre. Stem Cell Rep. 2015, 4, 541-550. [CrossRef]

49. Sanchez-Gurmaches, J.; Guertin, D.A. Adipocytes arise from multiple lineages that are heterogeneously and dynamically distributed. Nat. Commun. 2014, 5, 4099. [CrossRef]

50. Sanchez-Gurmaches, J.; Hung, C.M.; Sparks, C.A.; Tang, Y.; Li, H.; Guertin, D.A. PTEN loss in the Myf5 lineage redistributes body fat and reveals subsets of white adipocytes that arise from Myf5 precursors. Cell Metab. 2012, 16, 348-362. [CrossRef]

51. Trapnell, C. Defining cell types and states with single-cell genomics. Genome Res. 2015, 25, 1491-1498. [CrossRef]

52. Rondini, E.A.; Granneman, J.G. Single cell approaches to address adipose tissue stromal cell heterogeneity. Biochem. J. 2020, 477, 583-600. [CrossRef] [PubMed]

53. Burl, R.B.; Ramseyer, V.D.; Rondini, E.A.; Pique-Regi, R.; Lee, Y.H.; Granneman, J.G. Deconstructing Adipogenesis Induced by beta3-Adrenergic Receptor Activation with Single-Cell Expression Profiling. Cell Metab. 2018, 28, 300-309.e304. [CrossRef] [PubMed]

54. Hepler, C.; Shan, B.; Zhang, Q.; Henry, G.H.; Shao, M.; Vishvanath, L.; Ghaben, A.L.; Mobley, A.B.; Strand, D.; Hon, G.C.; et al. Identification of functionally distinct fibro-inflammatory and adipogenic stromal subpopulations in visceral adipose tissue of adult mice. Elife 2018, 7. [CrossRef]

55. Merrick, D.; Sakers, A.; Irgebay, Z.; Okada, C.; Calvert, C.; Morley, M.P.; Percec, I.; Seale, P. Identification of a mesenchymal progenitor cell hierarchy in adipose tissue. Science 2019, 364. [CrossRef] [PubMed]

56. Schwalie, P.C.; Dong, H.; Zachara, M.; Russeil, J.; Alpern, D.; Akchiche, N.; Caprara, C.; Sun, W.; Schlaudraff, K.U.; Soldati, G.; et al. A stromal cell population that inhibits adipogenesis in mammalian fat depots. Nature 2018, 559, 103-108. [CrossRef] [PubMed]

57. Dominici, M.; Le Blanc, K.; Mueller, I.; Slaper-Cortenbach, I.; Marini, F.; Krause, D.; Deans, R.; Keating, A.; Prockop, D.; Horwitz, E. Minimal criteria for defining multipotent mesenchymal stromal cells. The International Society for Cellular Therapy position statement. Cytotherapy 2006, 8, 315-317. [CrossRef]

58. Mildmay-White, A.; Khan, W. Cell Surface Markers on Adipose-Derived Stem Cells: A Systematic Review. Curr. Stem Cell Res. 2017, 12, 484-492. [CrossRef]

59. Van Harmelen, V.; Rohrig, K.; Hauner, H. Comparison of proliferation and differentiation capacity of human adipocyte precursor cells from the omental and subcutaneous adipose tissue depot of obese subjects. Metabolism 2004, 53, 632-637. [CrossRef]

60. Tchoukalova, Y.; Koutsari, C.; Jensen, M. Committed subcutaneous preadipocytes are reduced in human obesity. Diabetologia 2007, 50, 151-157. [CrossRef]

61. Onate, B.; Vilahur, G.; Ferrer-Lorente, R.; Ybarra, J.; Diez-Caballero, A.; Ballesta-Lopez, C.; Moscatiello, F.; Herrero, J.; Badimon, L. The subcutaneous adipose tissue reservoir of functionally active stem cells is reduced in obese patients. FASEB J. 2012, 26, 4327-4336. [CrossRef]

62. Isakson, P.; Hammarstedt, A.; Gustafson, B.; Smith, U. Impaired preadipocyte differentiation in human abdominal obesity: Role of Wnt, tumor necrosis factor-alpha, and inflammation. Diabetes 2009, 58, 1550-1557. [CrossRef] [PubMed]

63. Baglioni, S.; Cantini, G.; Poli, G.; Francalanci, M.; Squecco, R.; Di Franco, A.; Borgogni, E.; Frontera, S.; Nesi, G.; Liotta, F.; et al. Functional differences in visceral and subcutaneous fat pads originate from differences in the adipose stem cell. PLoS ONE 2012, 7, e36569. [CrossRef] [PubMed]

64. Silva, K.R.; Cortes, I.; Liechocki, S.; Carneiro, J.R.; Souza, A.A.; Borojevic, R.; Maya-Monteiro, C.M.; Baptista, L.S. Characterization of stromal vascular fraction and adipose stem cells from subcutaneous, preperitoneal and visceral morbidly obese human adipose tissue depots. PLoS ONE 2017, 12, e0174115. [CrossRef] [PubMed]

65. Joe, A.W.; Yi, L.; Even, Y.; Vogl, A.W.; Rossi, F.M. Depot-specific differences in adipogenic progenitor abundance and proliferative response to high-fat diet. Stem Cells 2009, 27, 2563-2570. [CrossRef] 
66. Meissburger, B.; Perdikari, A.; Moest, H.; Muller, S.; Geiger, M.; Wolfrum, C. Regulation of adipogenesis by paracrine factors from adipose stromal-vascular fraction-A link to fat depot-specific differences. Biochim. Biophys. Acta 2016, 1861, 1121-1131. [CrossRef]

67. Ogawa, R.; Mizuno, H.; Watanabe, A.; Migita, M.; Shimada, T.; Hyakusoku, H. Osteogenic and chondrogenic differentiation by adipose-derived stem cells harvested from GFP transgenic mice. Biochem. Biophys. Res. Commun. 2004, 313, 871-877. [CrossRef]

68. Huang, J.I.; Zuk, P.A.; Jones, N.F.; Zhu, M.; Lorenz, H.P.; Hedrick, M.H.; Benhaim, P. Chondrogenic potential of multipotential cells from human adipose tissue. Plast. Reconstr. Surg. 2004, 113, 585-594. [CrossRef]

69. Mizuno, H.; Zuk, P.A.; Zhu, M.; Lorenz, H.P.; Benhaim, P.; Hedrick, M.H. Myogenic differentiation by human processed lipoaspirate cells. Plast. Reconstr. Surg. 2002, 109, 199-209, discussion 210-211. [CrossRef]

70. Safford, K.M.; Hicok, K.C.; Safford, S.D.; Halvorsen, Y.D.; Wilkison, W.O.; Gimble, J.M.; Rice, H.E. Neurogenic differentiation of murine and human adipose-derived stromal cells. Biochem. Biophys. Res. Commun. 2002, 294, 371-379. [CrossRef]

71. Feve, B. Adipogenesis: Cellular and molecular aspects. Best Pr. Res. Clin. Endocrinol. Metab. 2005, 19, 483-499. [CrossRef]

72. Lefterova, M.I.; Haakonsson, A.K.; Lazar, M.A.; Mandrup, S. PPARgamma and the global map of adipogenesis and beyond. Trends Endocrinol. Metab. 2014, 25, 293-302. [CrossRef] [PubMed]

73. Jiang, Y.; Berry, D.C.; Jo, A.; Tang, W.; Arpke, R.W.; Kyba, M.; Graff, J.M. A PPARgamma transcriptional cascade directs adipose progenitor cell-niche interaction and niche expansion. Nat. Commun. 2017, 8, 15926. [CrossRef]

74. Rosen, E.D.; MacDougald, O.A. Adipocyte differentiation from the inside out. Nat. Rev. Mol. Cell Biol. 2006, 7, 885-896. [CrossRef] [PubMed]

75. Chen, Q.; Shou, P.; Zheng, C.; Jiang, M.; Cao, G.; Yang, Q.; Cao, J.; Xie, N.; Velletri, T.; Zhang, X.; et al. Fate decision of mesenchymal stem cells: Adipocytes or osteoblasts? Cell Death Differ. 2016, 23, 1128-1139. [CrossRef]

76. Wu, Z.; Rosen, E.D.; Brun, R.; Hauser, S.; Adelmant, G.; Troy, A.E.; McKeon, C.; Darlington, G.J.; Spiegelman, B.M. Cross-regulation of C/EBP alpha and PPAR gamma controls the transcriptional pathway of adipogenesis and insulin sensitivity. Mol. Cell 1999, 3, 151-158. [CrossRef]

77. Rosen, E.D.; Hsu, C.H.; Wang, X.; Sakai, S.; Freeman, M.W.; Gonzalez, F.J.; Spiegelman, B.M. C/EBPalpha induces adipogenesis through PPARgamma: A unified pathway. Genes Dev. 2002, 16, 22-26. [CrossRef]

78. Rosen, E.D.; Spiegelman, B.M. Molecular regulation of adipogenesis. Annu. Rev. Cell Dev. Biol. 2000, 16, 145-171. [CrossRef]

79. James, A.W.; Leucht, P.; Levi, B.; Carre, A.L.; Xu, Y.; Helms, J.A.; Longaker, M.T. Sonic Hedgehog influences the balance of osteogenesis and adipogenesis in mouse adipose-derived stromal cells. Tissue Eng. Part A 2010, 16, 2605-2616. [CrossRef]

80. Markarian, C.F.; Frey, G.Z.; Silveira, M.D.; Chem, E.M.; Milani, A.R.; Ely, P.B.; Horn, A.P.; Nardi, N.B.; Camassola, M. Isolation of adipose-derived stem cells: A comparison among different methods. Biotechnol. Lett. 2014, 36, 693-702. [CrossRef]

81. Ahearne, M.; Lysaght, J.; Lynch, A.P. Combined influence of basal media and fibroblast growth factor on the expansion and differentiation capabilities of adipose-derived stem cells. Cell Regen. 2014, 3, 13. [CrossRef]

82. Beederman, M.; Lamplot, J.D.; Nan, G.; Wang, J.; Liu, X.; Yin, L.; Li, R.; Shui, W.; Zhang, H.; Kim, S.H.; et al. BMP signaling in mesenchymal stem cell differentiation and bone formation. J. Biomed. Sci. Eng. 2013, 6, 32-52. [CrossRef] [PubMed]

83. Tsang, E.J.; Wu, B.; Zuk, P. MAPK signaling has stage-dependent osteogenic effects on human adipose-derived stem cells in vitro. Connect. Tissue Res. 2018, 59, 129-146. [CrossRef] [PubMed]

84. Wu, M.; Chen, G.; Li, Y.P. TGF-beta and BMP signaling in osteoblast, skeletal development, and bone formation, homeostasis and disease. Bone Res. 2016, 4, 16009. [CrossRef] [PubMed]

85. Gu, H.; Huang, Z.; Yin, X.; Zhang, J.; Gong, L.; Chen, J.; Rong, K.; Xu, J.; Lu, L.; Cui, L. Role of c-Jun $\mathrm{N}$-terminal kinase in the osteogenic and adipogenic differentiation of human adipose-derived mesenchymal stem cells. Exp. Cell Res. 2015, 339, 112-121. [CrossRef]

86. Boeuf, S.; Richter, W. Chondrogenesis of mesenchymal stem cells: Role of tissue source and inducing factors. Stem Cell Res. Ther. 2010, 1, 31. [CrossRef] 
87. Somoza, R.A.; Welter, J.F.; Correa, D.; Caplan, A.I. Chondrogenic differentiation of mesenchymal stem cells: Challenges and unfulfilled expectations. Tissue Eng. Part B Rev. 2014, 20, 596-608. [CrossRef]

88. Planat-Benard, V.; Silvestre, J.S.; Cousin, B.; Andre, M.; Nibbelink, M.; Tamarat, R.; Clergue, M.; Manneville, C.; Saillan-Barreau, C.; Duriez, M.; et al. Plasticity of human adipose lineage cells toward endothelial cells: Physiological and therapeutic perspectives. Circulation 2004, 109, 656-663. [CrossRef]

89. Martinez-Estrada, O.M.; Munoz-Santos, Y.; Julve, J.; Reina, M.; Vilaro, S. Human adipose tissue as a source of Flk-1+ cells: New method of differentiation and expansion. Cardiovasc. Res. 2005, 65, 328-333. [CrossRef]

90. Cao, Y.; Sun, Z.; Liao, L.; Meng, Y.; Han, Q.; Zhao, R.C. Human adipose tissue-derived stem cells differentiate into endothelial cells in vitro and improve postnatal neovascularization in vivo. Biochem. Biophys. Res. Commun. 2005, 332, 370-379. [CrossRef]

91. Zhang, P.; Moudgill, N.; Hager, E.; Tarola, N.; Dimatteo, C.; McIlhenny, S.; Tulenko, T.; DiMuzio, P.J. Endothelial differentiation of adipose-derived stem cells from elderly patients with cardiovascular disease. Stem Cells Dev. 2011, 20, 977-988. [CrossRef]

92. Jack, G.S.; Almeida, F.G.; Zhang, R.; Alfonso, Z.C.; Zuk, P.A.; Rodriguez, L.V. Processed lipoaspirate cells for tissue engineering of the lower urinary tract: Implications for the treatment of stress urinary incontinence and bladder reconstruction. J. Urol. 2005, 174, 2041-2045. [CrossRef]

93. Rodriguez, L.V.; Alfonso, Z.; Zhang, R.; Leung, J.; Wu, B.; Ignarro, L.J. Clonogenic multipotent stem cells in human adipose tissue differentiate into functional smooth muscle cells. Proc. Natl. Acad. Sci. USA 2006, 103, 12167-12172. [CrossRef] [PubMed]

94. Zhang, X.; Bendeck, M.P.; Simmons, C.A.; Santerre, J.P. Deriving vascular smooth muscle cells from mesenchymal stromal cells: Evolving differentiation strategies and current understanding of their mechanisms. Biomaterials 2017, 145, 9-22. [CrossRef] [PubMed]

95. Planat-Benard, V.; Menard, C.; Andre, M.; Puceat, M.; Perez, A.; Garcia-Verdugo, J.M.; Penicaud, L.; Casteilla, L. Spontaneous cardiomyocyte differentiation from adipose tissue stroma cells. Circ. Res. 2004, 94, 223-229. [CrossRef] [PubMed]

96. Mazo, M.; Planat-Benard, V.; Abizanda, G.; Pelacho, B.; Leobon, B.; Gavira, J.J.; Penuelas, I.; Cemborain, A.; Penicaud, L.; Laharrague, P.; et al. Transplantation of adipose derived stromal cells is associated with functional improvement in a rat model of chronic myocardial infarction. Eur. J. Heart Fail. 2008, 10, 454-462. [CrossRef]

97. Bel, A.; Planat-Bernard, V.; Saito, A.; Bonnevie, L.; Bellamy, V.; Sabbah, L.; Bellabas, L.; Brinon, B.; Vanneaux, V.; Pradeau, P.; et al. Composite cell sheets: A further step toward safe and effective myocardial regeneration by cardiac progenitors derived from embryonic stem cells. Circulation 2010, 122, S118-S123. [CrossRef]

98. Madonna, R.; De Caterina, R. In vitro neovasculogenic potential of resident adipose tissue precursors. Am. J. Physiol. Cell Physiol. 2008, 295, C1271-C1280. [CrossRef]

99. Sumi, M.; Sata, M.; Toya, N.; Yanaga, K.; Ohki, T.; Nagai, R. Transplantation of adipose stromal cells, but not mature adipocytes, augments ischemia-induced angiogenesis. Life Sci. 2007, 80, 559-565. [CrossRef]

100. Nagata, H.; Ii, M.; Kohbayashi, E.; Hoshiga, M.; Hanafusa, T.; Asahi, M. Cardiac Adipose-Derived Stem Cells Exhibit High Differentiation Potential to Cardiovascular Cells in C57BL/6 Mice. Stem Cells Transl. Med. 2016, 5, 141-151. [CrossRef]

101. Wystrychowski, W.; Patlolla, B.; Zhuge, Y.; Neofytou, E.; Robbins, R.C.; Beygui, R.E. Multipotency and cardiomyogenic potential of human adipose-derived stem cells from epicardium, pericardium, and omentum. Stem Cell Res. Ther. 2016, 7, 84. [CrossRef]

102. Thery, C.; Witwer, K.W.; Aikawa, E.; Alcaraz, M.J.; Anderson, J.D.; Andriantsitohaina, R.; Antoniou, A.; Arab, T.; Archer, F.; Atkin-Smith, G.K.; et al. Minimal information for studies of extracellular vesicles 2018 (MISEV2018): A position statement of the International Society for Extracellular Vesicles and update of the MISEV2014 guidelines. J. Extracell. Vesicles 2018, 7, 1535750. [CrossRef] [PubMed]

103. Kranendonk, M.E.; Visseren, F.L.; van Balkom, B.W.; Nolte-'t Hoen, E.N.; van Herwaarden, J.A.; de Jager, W.; Schipper, H.S.; Brenkman, A.B.; Verhaar, M.C.; Wauben, M.H.; et al. Human adipocyte extracellular vesicles in reciprocal signaling between adipocytes and macrophages. Obesity (Silver Spring) 2014, 22, 1296-1308. [CrossRef] [PubMed]

104. Koeck, E.S.; Iordanskaia, T.; Sevilla, S.; Ferrante, S.C.; Hubal, M.J.; Freishtat, R.J.; Nadler, E.P. Adipocyte exosomes induce transforming growth factor beta pathway dysregulation in hepatocytes: A novel paradigm for obesity-related liver disease. J. Surg Res. 2014, 192, 268-275. [CrossRef] [PubMed] 
105. Connolly, K.D.; Guschina, I.A.; Yeung, V.; Clayton, A.; Draman, M.S.; Von Ruhland, C.; Ludgate, M.; James, P.E.; Rees, D.A. Characterisation of adipocyte-derived extracellular vesicles released pre- and post-adipogenesis. J. Extracell. Vesicles 2015, 4, 29159. [CrossRef]

106. Chen, L.; Dai, Y.M.; Ji, C.B.; Yang, L.; Shi, C.M.; Xu, G.F.; Pang, L.X.; Huang, F.Y.; Zhang, C.M.; Guo, X.R. MiR-146b is a regulator of human visceral preadipocyte proliferation and differentiation and its expression is altered in human obesity. Mol. Cell. Endocrinol. 2014, 393, 65-74. [CrossRef]

107. Li, M.; Liu, Z.; Zhang, Z.; Liu, G.; Sun, S.; Sun, C. miR-103 promotes 3T3-L1 cell adipogenesis through AKT/mTOR signal pathway with its target being MEF2D. Biol. Chem. 2015, 396, 235. [CrossRef]

108. Londono Gentile, T.; Lu, C.; Lodato, P.M.; Tse, S.; Olejniczak, S.H.; Witze, E.S.; Thompson, C.B.; Wellen, K.E. DNMT1 is regulated by ATP-citrate lyase and maintains methylation patterns during adipocyte differentiation. Mol. Cell. Biol. 2013, 33, 3864-3878. [CrossRef]

109. Ogawa, R.; Tanaka, C.; Sato, M.; Nagasaki, H.; Sugimura, K.; Okumura, K.; Nakagawa, Y.; Aoki, N. Adipocyte-derived microvesicles contain RNA that is transported into macrophages and might be secreted into blood circulation. Biochem. Biophys. Res. Commun. 2010, 398, 723-729. [CrossRef]

110. Phoonsawat, W.; Aoki-Yoshida, A.; Tsuruta, T.; Sonoyama, K. Adiponectin is partially associated with exosomes in mouse serum. Biochem. Biophys. Res. Commun. 2014, 448, 261-266. [CrossRef]

111. DeClercq, V.; d'Eon, B.; McLeod, R.S. Fatty acids increase adiponectin secretion through both classical and exosome pathways. Biochim. Biophys. Acta 2015, 1851, 1123-1133. [CrossRef]

112. Sano, S.; Izumi, Y.; Yamaguchi, T.; Yamazaki, T.; Tanaka, M.; Shiota, M.; Osada-Oka, M.; Nakamura, Y.; Wei, M.; Wanibuchi, H.; et al. Lipid synthesis is promoted by hypoxic adipocyte-derived exosomes in 3T3-L1 cells. Biochem. Biophys. Res. Commun. 2014, 445, 327-333. [CrossRef]

113. Baglio, S.R.; Rooijers, K.; Koppers-Lalic, D.; Verweij, F.J.; Perez Lanzon, M.; Zini, N.; Naaijkens, B.; Perut, F.; Niessen, H.W.; Baldini, N.; et al. Human bone marrow- and adipose-mesenchymal stem cells secrete exosomes enriched in distinctive miRNA and tRNA species. Stem Cell Res. Ther. 2015, 6, 127. [CrossRef] [PubMed]

114. Kalinina, N.; Kharlampieva, D.; Loguinova, M.; Butenko, I.; Pobeguts, O.; Efimenko, A.; Ageeva, L.; Sharonov, G.; Ischenko, D.; Alekseev, D.; et al. Characterization of secretomes provides evidence for adipose-derived mesenchymal stromal cells subtypes. Stem Cell Res. Ther. 2015, 6, 221. [CrossRef] [PubMed]

115. Lopatina, T.; Bruno, S.; Tetta, C.; Kalinina, N.; Porta, M.; Camussi, G. Platelet-derived growth factor regulates the secretion of extracellular vesicles by adipose mesenchymal stem cells and enhances their angiogenic potential. Cell Commun. Signal. 2014, 12, 26. [CrossRef] [PubMed]

116. Pascucci, L.; Alessandri, G.; Dall'Aglio, C.; Mercati, F.; Coliolo, P.; Bazzucchi, C.; Dante, S.; Petrini, S.; Curina, G.; Ceccarelli, P. Membrane vesicles mediate pro-angiogenic activity of equine adipose-derived mesenchymal stromal cells. Vet. J. 2014, 202, 361-366. [CrossRef]

117. Jayabalan, N.; Lai, A.; Ormazabal, V.; Adam, S.; Guanzon, D.; Palma, C.; Scholz-Romero, K.; Lim, R.; Jansson, T.; McIntyre, H.D.; et al. Adipose Tissue Exosomal Proteomic Profile Reveals a Role on Placenta Glucose Metabolism in Gestational Diabetes Mellitus. J. Clin. Endocrinol. Metab. 2019, 104, 1735-1752. [CrossRef] [PubMed]

118. Barnea, M.; Chapnik, N.; Genzer, Y.; Froy, O. The circadian clock machinery controls adiponectin expression. Mol. Cell. Endocrinol. 2015, 399, 284-287. [CrossRef]

119. McLaughlin, T.; Sherman, A.; Tsao, P.; Gonzalez, O.; Yee, G.; Lamendola, C.; Reaven, G.M.; Cushman, S.W. Enhanced proportion of small adipose cells in insulin-resistant vs insulin-sensitive obese individuals implicates impaired adipogenesis. Diabetologia 2007, 50, 1707-1715. [CrossRef]

120. Muller, G. Let's shift lipid burden-From large to small adipocytes. Eur. J. Pharm. 2011, 656, 1-4. [CrossRef]

121. Muller, G. Microvesicles/exosomes as potential novel biomarkers of metabolic diseases. Diabetes Metab. Syndr. Obes. Targets Ther. 2012, 5, 247-282. [CrossRef]

122. Eguchi, A.; Mulya, A.; Lazic, M.; Radhakrishnan, D.; Berk, M.P.; Povero, D.; Gornicka, A.; Feldstein, A.E. Microparticles release by adipocytes act as "find-me" signals to promote macrophage migration. PLoS ONE 2015, 10, e0123110. [CrossRef]

123. Eguchi, A.; Lazic, M.; Armando, A.M.; Phillips, S.A.; Katebian, R.; Maraka, S.; Quehenberger, O.; Sears, D.D.; Feldstein, A.E. Circulating adipocyte-derived extracellular vesicles are novel markers of metabolic stress. J. Mol. Med. 2016, 94, 1241-1253. [CrossRef] 
124. Kanhai, D.A.; Visseren, F.L.; van der Graaf, Y.; Schoneveld, A.H.; Catanzariti, L.M.; Timmers, L.; Kappelle, L.J.; Uiterwaal, C.S.; Lim, S.K.; Sze, S.K.; et al. Microvesicle protein levels are associated with increased risk for future vascular events and mortality in patients with clinically manifest vascular disease. Int. J. Cardiol. 2013, 168, 2358-2363. [CrossRef]

125. Kranendonk, M.E.; de Kleijn, D.P.; Kalkhoven, E.; Kanhai, D.A.; Uiterwaal, C.S.; van der Graaf, Y.; Pasterkamp, G.; Visseren, F.L.; Group, S.S. Extracellular vesicle markers in relation to obesity and metabolic complications in patients with manifest cardiovascular disease. Cardiovasc. Diabetol. 2014, 13, 37. [CrossRef] [PubMed]

126. Zhang, Y.; Yu, M.; Tian, W. Physiological and pathological impact of exosomes of adipose tissue. Cell Prolif. 2016, 49, 3-13. [CrossRef] [PubMed]

127. Ertunc, M.E.; Sikkeland, J.; Fenaroli, F.; Griffiths, G.; Daniels, M.P.; Cao, H.; Saatcioglu, F.; Hotamisligil, G.S. Secretion of fatty acid binding protein aP2 from adipocytes through a nonclassical pathway in response to adipocyte lipase activity. J. Lipid Res. 2015, 56, 423-434. [CrossRef] [PubMed]

128. Patel, R.S.; Carter, G.; El Bassit, G.; Patel, A.A.; Cooper, D.R.; Murr, M.; Patel, N.A. Adipose-derived stem cells from lean and obese humans show depot specific differences in their stem cell markers, exosome contents and senescence: Role of protein kinase C delta (PKCdelta) in adipose stem cell niche. Stem Cell Investig. 2016, 3, 2. [CrossRef]

129. Sailon, A.M.; Wasserburg, J.R.; Kling, R.R.; Pasick, C.M.; Taub, P.J. Influence of Large-Volume Liposuction on Metabolic and Cardiovascular Health: A Systematic Review. Ann. Plast. Surg. 2017, 79, 623-630. [CrossRef]

130. Robles-Cervantes, J.A.; Yanez-Diaz, S.; Cardenas-Camarena, L. Modification of insulin, glucose and cholesterol levels in nonobese women undergoing liposuction: Is liposuction metabolically safe? Ann. Plast. Surg. 2004, 52, 64-67. [CrossRef]

131. Kahn, C.R.; Wang, G.; Lee, K.Y. Altered adipose tissue and adipocyte function in the pathogenesis of metabolic syndrome. J. Clin. Investig. 2019, 129, 3990-4000. [CrossRef]

132. Ortega, F.J.; Moreno-Navarrete, J.M.; Pardo, G.; Sabater, M.; Hummel, M.; Ferrer, A.; Rodriguez-Hermosa, J.I.; Ruiz, B.; Ricart, W.; Peral, B.; et al. MiRNA expression profile of human subcutaneous adipose and during adipocyte differentiation. PLoS ONE 2010, 5, e9022. [CrossRef] [PubMed]

133. Gao, X.; Salomon, C.; Freeman, D.J. Extracellular Vesicles from Adipose Tissue-A Potential Role in Obesity and Type 2 Diabetes? Front. Endocrinol. 2017, 8, 202. [CrossRef] [PubMed]

134. Zhao, H.; Shang, Q.; Pan, Z.; Bai, Y.; Li, Z.; Zhang, H.; Zhang, Q.; Guo, C.; Zhang, L.; Wang, Q. Exosomes From Adipose-Derived Stem Cells Attenuate Adipose Inflammation and Obesity Through Polarizing M2 Macrophages and Beiging in White Adipose Tissue. Diabetes 2018, 67, 235-247. [CrossRef]

135. Huang, B.; Huang, L.F.; Zhao, L.; Zeng, Z.; Wang, X.; Cao, D.; Yang, L.; Ye, Z.; Chen, X.; Liu, B.; et al. Microvesicles (MIVs) secreted from adipose-derived stem cells (ADSCs) contain multiple microRNAs and promote the migration and invasion of endothelial cells. Genes Dis. 2020, 7, 225-234. [CrossRef] [PubMed]

136. Thomou, T.; Mori, M.A.; Dreyfuss, J.M.; Konishi, M.; Sakaguchi, M.; Wolfrum, C.; Rao, T.N.; Winnay, J.N.; Garcia-Martin, R.; Grinspoon, S.K.; et al. Adipose-derived circulating miRNAs regulate gene expression in other tissues. Nature 2017, 542, 450-455. [CrossRef] [PubMed]

137. Togliatto, G.; Dentelli, P.; Gili, M.; Gallo, S.; Deregibus, C.; Biglieri, E.; Iavello, A.; Santini, E.; Rossi, C.; Solini, A.; et al. Obesity reduces the pro-angiogenic potential of adipose tissue stem cell-derived extracellular vesicles (EVs) by impairing miR-126 content: Impact on clinical applications. Int. J. Obes. 2016, 40, 102-111. [CrossRef]

138. Meng, Y.; Eirin, A.; Zhu, X.Y.; Tang, H.; Chanana, P.; Lerman, A.; Van Wijnen, A.J.; Lerman, L.O. The metabolic syndrome alters the miRNA signature of porcine adipose tissue-derived mesenchymal stem cells. Cytom. Part A J. Int. Soc. Anal. Cytol. 2018, 93, 93-103. [CrossRef]

139. Meng, Y.; Eirin, A.; Zhu, X.Y.; Tang, H.; Hickson, L.J.; Lerman, A.; van Wijnen, A.J.; Lerman, L.O. Micro-RNAS Regulate Metabolic Syndrome-induced Senescence in Porcine Adipose Tissue-derived Mesenchymal Stem Cells through the P16/MAPK Pathway. Cell Transplant. 2018, 27, 1495-1503. [CrossRef]

140. Cooper, D.R.; Wang, C.; Patel, R.; Trujillo, A.; Patel, N.A.; Prather, J.; Gould, L.J.; Wu, M.H. Human Adipose-Derived Stem Cell Conditioned Media and Exosomes Containing MALAT1 Promote Human Dermal Fibroblast Migration and Ischemic Wound Healing. Adv. Wound Care 2018, 7, 299-308. [CrossRef]

141. Li, Z.X.; Zhu, Q.N.; Zhang, H.B.; Hu, Y.; Wang, G.; Zhu, Y.S. MALAT1: A potential biomarker in cancer. Cancer Manag. Res. 2018, 10, 6757-6768. [CrossRef] 
142. Hong, P.; Yang, H.; Wu, Y.; Li, K.; Tang, Z. The functions and clinical application potential of exosomes derived from adipose mesenchymal stem cells: A comprehensive review. Stem Cell Res. Ther. 2019, 10, 242. [CrossRef] [PubMed]

143. Henson, J.B.; Simon, T.G.; Kaplan, A.; Osganian, S.; Masia, R.; Corey, K.E. Advanced fibrosis is associated with incident cardiovascular disease in patients with non-alcoholic fatty liver disease. Aliment. Pharmacol. Ther. 2020, 51, 728-736. [CrossRef]

144. Kumar, R.; Priyadarshi, R.N.; Anand, U. Non-alcoholic Fatty Liver Disease: Growing Burden, Adverse Outcomes and Associations. J. Clin. Transl. Hepatol. 2020, 8, 76-86. [CrossRef]

145. Li, T.; Yan, Y.; Wang, B.; Qian, H.; Zhang, X.; Shen, L.; Wang, M.; Zhou, Y.; Zhu, W.; Li, W.; et al. Exosomes derived from human umbilical cord mesenchymal stem cells alleviate liver fibrosis. Stem Cells Dev. 2013, 22, 845-854. [CrossRef] [PubMed]

146. Qu, Y.; Zhang, Q.; Cai, X.; Li, F.; Ma, Z.; Xu, M.; Lu, L. Exosomes derived from miR-181-5p-modified adipose-derived mesenchymal stem cells prevent liver fibrosis via autophagy activation. J. Cell. Mol. Med. 2017, 21, 2491-2502. [CrossRef] [PubMed]

147. Kranendonk, M.E.; Visseren, F.L.; van Herwaarden, J.A.; Nolte-'t Hoen, E.N.; de Jager, W.; Wauben, M.H.; Kalkhoven, E. Effect of extracellular vesicles of human adipose tissue on insulin signaling in liver and muscle cells. Obesity 2014, 22, 2216-2223. [CrossRef]

148. Ormazabal, V.; Nair, S.; Elfeky, O.; Aguayo, C.; Salomon, C.; Zuniga, F.A. Association between insulin resistance and the development of cardiovascular disease. Cardiovasc. Diabetol. 2018, 17, 122. [CrossRef]

149. Deng, S.; Zhou, X.; Ge, Z.; Song, Y.; Wang, H.; Liu, X.; Zhang, D. Exosomes from adipose-derived mesenchymal stem cells ameliorate cardiac damage after myocardial infarction by activating S1P/SK1/S1PR1 signaling and promoting macrophage M2 polarization. Int. J. Biochem. Cell Biol. 2019, 114, 105564. [CrossRef]

150. Luo, Q.; Guo, D.; Liu, G.; Chen, G.; Hang, M.; Jin, M. Exosomes from MiR-126-Overexpressing Adscs Are Therapeutic in Relieving Acute Myocardial Ischaemic Injury. Cell. Physiol. Biochem. Int. J. Exp. Cell. Physiol. Biochem. Pharmacol. 2017, 44, 2105-2116. [CrossRef]

151. Liu, J.; Jiang, M.; Deng, S.; Lu, J.; Huang, H.; Zhang, Y.; Gong, P.; Shen, X.; Ruan, H.; Jin, M.; et al. miR-93-5p-Containing Exosomes Treatment Attenuates Acute Myocardial Infarction-Induced Myocardial Damage. Mol. Ther. Nucleic Acids 2018, 11, 103-115. [CrossRef]

152. Wang, J.; Yi, Y.; Zhu, Y.; Wang, Z.; Wu, S.; Zhang, J.; Hu, X.; Nie, J. Effects of adipose-derived stem cell released exosomes on wound healing in diabetic mice. Zhongguo Xiu Fu Chong Jian Wai Ke Za Zhi Zhongguo Xiufu Chongjian Waike Zazhi Chin. J. Reparative Reconstr. Surg. 2020, 34, 124-131. [CrossRef]

153. Hu, X.; Yi, Y.; Zhu, Y.; Wang, Z.; Wu, S.; Zhang, J.; Wang, J.; Nie, J. Effect of adipose-derived stem cell derived exosomes on angiogenesis after skin flap transplantation in rats. Zhongguo Xiu Fu Chong Jian Wai Ke Za Zhi Zhongguo Xiufu Chongjian Waike Zazhi Chin. J. Reparative Reconstr. Surg. 2019, 33, 1560-1565. [CrossRef]

154. Zhang, W.; Bai, X.; Zhao, B.; Li, Y.; Zhang, Y.; Li, Z.; Wang, X.; Luo, L.; Han, F.; Zhang, J.; et al. Cell-free therapy based on adipose tissue stem cell-derived exosomes promotes wound healing via the PI3K/Akt signaling pathway. Exp. Cell Res. 2018, 370, 333-342. [CrossRef]

155. Bai, Y.; Han, Y.D.; Yan, X.L.; Ren, J.; Zeng, Q.; Li, X.D.; Pei, X.T.; Han, Y. Adipose mesenchymal stem cell-derived exosomes stimulated by hydrogen peroxide enhanced skin flap recovery in ischemia-reperfusion injury. Biochem. Biophys. Res. Commun. 2018, 500, 310-317. [CrossRef]

156. Fan, M.; Bai, J.; Ding, T.; Yang, X.; Si, Q.; Nie, D. Adipose-Derived Stem Cell Transplantation Inhibits Vascular Inflammatory Responses and Endothelial Dysfunction in Rats with Atherosclerosis. Yonsei Med. J. 2019, 60, 1036-1044. [CrossRef]

157. Xing, X.; Li, Z.; Yang, X.; Li, M.; Liu, C.; Pang, Y.; Zhang, L.; Li, X.; Liu, G.; Xiao, Y. Adipose-derived mesenchymal stem cells-derived exosome-mediated microRNA-342-5p protects endothelial cells against atherosclerosis. Aging 2020, 12, 3880-3898. [CrossRef] [PubMed]

158. Colazzo, F.; Alrashed, F.; Saratchandra, P.; Carubelli, I.; Chester, A.H.; Yacoub, M.H.; Taylor, P.M.; Somers, P. Shear stress and VEGF enhance endothelial differentiation of human adipose-derived stem cells. Growth Factors 2014, 32, 139-149. [CrossRef] [PubMed]

159. Lee, W.C.; Maul, T.M.; Vorp, D.A.; Rubin, J.P.; Marra, K.G. Effects of uniaxial cyclic strain on adipose-derived stem cell morphology, proliferation, and differentiation. Biomech. Model. Mechanobiol. 2007, 6, 265-273. [CrossRef] 
160. Wang, C.; Cen, L.; Yin, S.; Liu, Q.; Liu, W.; Cao, Y.; Cui, L. A small diameter elastic blood vessel wall prepared under pulsatile conditions from polyglycolic acid mesh and smooth muscle cells differentiated from adipose-derived stem cells. Biomaterials 2010, 31, 621-630. [CrossRef]

161. Zhao, X.; Liu, L.; Wang, J.; Xu, Y.; Zhang, W.; Khang, G.; Wang, X. In vitro vascularization of a combined system based on a 3D printing technique. J. Tissue Eng. Regen. Med. 2016, 10, 833-842. [CrossRef]

162. Marino, G.; Rosso, F.; Ferdinando, P.; Grimaldi, A.; De Biasio, G.; Cafiero, G.; Barbarisi, M.; Barbarisi, A. Growth and endothelial differentiation of adipose stem cells on polycaprolactone. J. Biomed. Mater. Res. Part A 2012, 100, 543-548. [CrossRef] [PubMed]

163. McIlhenny, S.E.; Hager, E.S.; Grabo, D.J.; DiMatteo, C.; Shapiro, I.M.; Tulenko, T.N.; DiMuzio, P.J. Linear shear conditioning improves vascular graft retention of adipose-derived stem cells by upregulation of the alpha5beta1 integrin. Tissue Eng. Part A 2010, 16, 245-255. [CrossRef] [PubMed]

164. Roosens, A.; Asadian, M.; De Geyter, N.; Somers, P.; Cornelissen, R. Complete Static Repopulation of Decellularized Porcine Tissues for Heart Valve Engineering: An in vitro Study. Cells Tissues Organs 2017, 204, 270-282. [CrossRef] [PubMed]

165. Arana, M.; Pena, E.; Abizanda, G.; Cilla, M.; Ochoa, I.; Gavira, J.J.; Espinosa, G.; Doblare, M.; Pelacho, B.; Prosper, F. Preparation and characterization of collagen-based ADSC-carrier sheets for cardiovascular application. Acta Biomater. 2013, 9, 6075-6083. [CrossRef] [PubMed]

166. Arana, M.; Gavira, J.J.; Pena, E.; Gonzalez, A.; Abizanda, G.; Cilla, M.; Perez, M.M.; Albiasu, E.; Aguado, N.; Casado, M.; et al. Epicardial delivery of collagen patches with adipose-derived stem cells in rat and minipig models of chronic myocardial infarction. Biomaterials 2014, 35, 143-151. [CrossRef]

167. Hamdi, H.; Planat-Benard, V.; Bel, A.; Puymirat, E.; Geha, R.; Pidial, L.; Nematalla, H.; Bellamy, V.; Bouaziz, P.; Peyrard, S.; et al. Epicardial adipose stem cell sheets results in greater post-infarction survival than intramyocardial injections. Cardiovasc. Res. 2011, 91, 483-491. [CrossRef] [PubMed]

168. Wang, K.; Yu, L.Y.; Jiang, L.Y.; Wang, H.B.; Wang, C.Y.; Luo, Y. The paracrine effects of adipose-derived stem cells on neovascularization and biocompatibility of a macroencapsulation device. Acta Biomater. 2015, 15, 65-76. [CrossRef]

Publisher's Note: MDPI stays neutral with regard to jurisdictional claims in published maps and institutional affiliations.

(C) 2020 by the authors. Licensee MDPI, Basel, Switzerland. This article is an open access article distributed under the terms and conditions of the Creative Commons Attribution (CC BY) license (http://creativecommons.org/licenses/by/4.0/). 